\title{
Establishment of injury models in studies of biological effects induced by microwave radiation
}

\author{
Yun-Fei Lai, Hao-Yu Wang ${ }^{*}$ and Rui-Yun Peng ${ }^{*}$
}

\begin{abstract}
Microwave radiation has been widely used in various fields, such as communication, industry, medical treatment, and military applications. Microwave radiation may cause injuries to both the structures and functions of various organs, such as the brain, heart, reproductive organs, and endocrine organs, which endanger human health. Therefore, it is both theoretically and clinically important to conduct studies on the biological effects induced by microwave radiation. The successful establishment of injury models is of great importance to the reliability and reproducibility of these studies. In this article, we review the microwave exposure conditions, subjects used to establish injury models, the methods used for the assessment of the injuries, and the indicators implemented to evaluate the success of injury model establishment in studies on biological effects induced by microwave radiation.
\end{abstract}

Keywords: Microwave radiation, Injury model, Biological effects, Methods, Biological indicators, Review

\section{Background}

The World Health Organization (WHO) has listed electromagnetic radiation as one of the most common and fastest growing environmental influences [1]. Microwave radiation is a form of electromagnetic waves, with frequencies ranging from $300 \mathrm{MHz}$ to $300 \mathrm{GHz}$. Microwave radiation has been widely used in various fields, such as communication, industry, medical treatment, and the military. Previous studies have shown that microwave radiation can cause injuries to both the structures and functions of the brain, heart, reproductive organs and endocrine organs, which endangers human health [2-9]. Studies on the biological effects induced by microwave radiation are essential for unveiling the mechanisms of these injuries and promoting the development of more efficient prevention methods and more profound treatment strategies. Successful establishment of injury models plays an important role in studies on the biological effects of microwave radiation. Not only is the successful establishment of injury models the premise of these studies, but it also has great importance to their reliability and reproducibility.

Generally, the establishment of injury models induced by microwave radiation requires stable microwave exposure conditions, suitable subjects, appropriate methods, and reliable biological indicators. The stable microwave exposure conditions promise the reproducibility of the microwave-radiation-induced biological effects [10]. Suitable subjects sensitive to specific microwave radiation injuries are essential in establishing different types of injury models. The appropriate methods are helpful in screening biological indicators sensitive to microwave radiation, which are important for assessing the successful establishment of injury models, understanding the underlying mechanisms of microwave radiation injuries, and laying foundations for corresponding clinical diagnosis and the development of targeted therapeutic drugs. 


\section{Microwave exposure conditions}

The microwave exposure conditions determine the reproducibility of the microwave-radiation-induced biological effects. The most commonly used parameters to depict the microwave exposure conditions in previous studies include the source frequency, the average incident power density, the specific absorption rate (SAR), the time variability and frequency variability, and the proximity of the subjects to the microwave exposure source.

The source frequency is one of the most important physical parameters of electromagnetic exposure. Microwave frequency bands, including the $\mathrm{L}$ band $(1-2 \mathrm{GHz})$ [11], $\mathrm{S}$ band $(2-4 \mathrm{GHz})$ [12-14], and $\mathrm{X}$ band $(8-12$ $\mathrm{GHz})[15,16]$, which are widely used in radar communication systems, were implemented in previous studies. In addition, frequencies such as $900 \mathrm{MHz}$ [17-22], 1800 $\mathrm{MHz}[18,22-24]$ (Global System for Mobile Communications signals), and $2450 \mathrm{MHz}$ [2, 25-34] (microwave oven and WiFi equipment) were also implemented in related studies.

The average power density is another significant physical parameter of electromagnetic exposure. The average power densities of $2.5,5,10,30$, and $50 \mathrm{~mW} / \mathrm{cm}^{2}$ were used to establish biological injury models to illuminate the relationship between the biological effects and the microwave radiation doses [4, 35-39]. For instance, Wang et al. [4] found that long-term microwave exposure (2.5 - 10.0 $\mathrm{mW} / \mathrm{cm}^{2}$ ) could cause spatial learning and memory deficits in rats, which were positively correlated with the average power densities. In addition, a microwave exposure system with lower average power densities ranging from $10^{-2} \mathrm{~mW} / \mathrm{cm}^{2}$ to $10^{-1} \mathrm{~mW} / \mathrm{cm}^{2}$ was also used to establish biological injury models [40-42].

The SAR value is an internationally accepted electromagnetic radiation dosimetric parameter. The SAR value distribution in animals or cells relies not only on the frequency, incident direction, and E-polarization direction but also on the structure of the subject under exposure and the electromagnetic properties of different tissues. To date, the SAR values implemented in studies on microwave radiation biological effects range from $10^{-4}$ $\mathrm{W} / \mathrm{kg}$ to $35 \mathrm{~W} / \mathrm{kg}[12,13,18,43]$.

The time variability on many time scales may influence the establishment of a microwave injury model. For example, microwave exposure can be classified into pulsed wave $(\mathrm{PW})$ exposure and continuous wave $(\mathrm{CW})$ exposure. Pulsed microwave exposure is characterized by its nonlinearity and instantaneous nature, which may be the reason why the adverse effects are more serious than those caused by continuous exposure [44]. Moreover, microwave exposure can also be classified as single exposure and multiple exposures based on the number of exposures. On the one hand, a single exposure was widely used in studies on biological effects after acute high-dose microwave radiation [38]. On the other hand, a multiple-exposure mode was implemented in studies on the biological effects of long-term low-dose microwave radiation [42, 45].

The frequency variability has also been studied. For instance, single-frequency and combined microwave exposures are classified according to their frequency domain properties. Most studies on microwave radiation exposure have focused on single-frequency exposure. In fact, simultaneous exposure to different frequency microwave radiation is closer to the real scenario. For example, an in vivo study reported that cognitive dysfunctions induced by combined exposure $(1.5 \mathrm{GHz}$ and $2.856 \mathrm{GHz})$ were more serious than those induced by singlefrequency exposure [11].

The proximity of the subjects to the microwave exposure source is another parameter that may influence the establishment of a microwave radiation injury model, since the mechanism of subject heating is different in near-field and far-field exposures (mostly electrical field driven vs radiation absorption). In medical applications, near-field effects are predominant, whereas in telecommunications, far-field effects are predominant [46-53].

Other exposure conditions that could influence the establishment of a microwave radiation injury model, including but not limited to the modulation, the waveform, chemical cofactors, whole-animal or headonly exposure, the duration of exposure, and the time between exposure and measurement, have also been investigated [54-64].

\section{Subjects used to establish injury models}

Appropriate subjects are the premises for establishing in vivo and in vitro injury models of microwave radiation. On the one hand, in vivo studies are crucial to explore the biological effects of microwave radiation in complex biological conditions. On the other hand, in vitro studies are often used to unveil the biological mechanisms. Since different subjects have different sensitivities to microwave radiation, the choice of animal species, cell types or other organisms should be determined by their special microwave sensitivities and the specific purpose of the study.

\section{Animal species}

Various animal species (rats, mice, rabbits, monkeys, etc.) have been used in studies on the biological effects of microwave radiation. Each of these animal species has a unique advantage in studying the biological effects of microwave radiation on specific target organs or tissues. 


\section{Rats}

Rats, including Wistar rats, Sprague-Dawley (SD) rats, and Fischer-344 rats, were widely used in studies on the biological effects of microwave radiation. Wistar rats were the most commonly used rodent for the detection of microwave-radiation-induced injury effects on target organs, such as the brain $[3,4,12,13,17,37,65-78]$, heart [79-83], reproductive organs [79, 83-86], and endocrine organs [6]. SD rats were mainly used in studies on the effects of microwave radiation on the brain [87-103], heart [104-108], and skin [109]. In addition, Fischer-344 rats were used to evaluate the biological effects of microwave radiation on cognitive function [110113] and the blood-brain barrier (BBB) [114-118].

\section{Mice}

Mouse species such as Kunming mice, Swiss mice, $\mathrm{BALB} / \mathrm{c}$ mice, C57BL/6 mice, and NMRI mice were also used in studies of the effects of microwave radiation on brain function. Among these species, Kunming mice were mainly chosen by Chinese scholars in their studies $[119,120]$. Swiss mice were more commonly used by scholars from other countries $[2,15,16,40,95,121-$ 123]. In addition, BALB/c mice were also used to study the effects of microwave radiation on learning and memory functions. Furthermore, NMRI mice [124] and C57BL/6 mice $[125,126]$ were widely used to study the effects of microwave radiation on locomotor activity.

In addition, several studies have been conducted with transgenic heterozygous and heterozygous knockout mice, which are prone to specific tumors. These mice were used to study tumorigenesis induced by microwave radiation [127, 128].

\section{Rabbits}

It is well known that rabbits are sensitive to stress, especially during pregnancy. Pregnant female rabbits can miscarry easily when they are under stress [129-131]. Furthermore, rabbits easily yield semen at the appointed time, which is suitable for longitudinal studies [132]. Therefore, New Zealand white rabbits were used to investigate the biological effects of microwave radiation on pregnant women, the developmental stages of children's brains from conception to childhood, and the male reproductive system [7, 129, 131-135].

Rabbits have also been used to establish microwave injury models of the brain, heart, spinal cord, and eye [136-139].

\section{Monkeys}

Since their corneas are similar to humans, rhesus monkeys (Macaca mulatta) were used to evaluate the bioeffects of microwave exposure on eyes [140-144]. The average thickness of the central cornea in rhesus monkeys is approximately $0.50 \mathrm{~mm}$, which is close to that of humans $(0.56 \mathrm{~mm})$. Furthermore, similar to humans, in rhesus monkeys, the corneal endothelium is not capable of mitotic potential under pathological conditions [141].

\section{Other animal species}

Poultry eggs were implemented as typical animal models in biological effect studies of microwave radiation on embryonic development due to the well-developed nervous system and short feeding cycle of chickens [23, 145]. For instance, Yakymenko et al. [23] reported an increased embryo mortality of developing quail embryos after exposure to the Global System for Mobile Communication (GSM) signal of $1800 \mathrm{MHz}$.

Transgenic nematodes have also been used to establish microwave injury models [146].

\section{Cell types}

Cell models are essential for studies on the biological mechanisms of microwave radiation injuries since they can exclude the influence of complex in vivo environments. The most widely used cell types in previous studies on microwave radiation injuries included neurons, germ cells, and heart cells.

\section{Neurons}

Neurons were often used in studies on brain injuries induced by microwave radiation. Previous studies implemented either primarily cultured neurons or neuron-like cell lines according to the specific scientific purposes and the advantages of different cell types. Primarily cultured neurons were isolated from in vivo rodent brains. Due to the indivisibility of mature neurons, they are not suitable for experiments that require a large number of cells. The primary cultured neurons used in previous studies on microwave radiation bioeffects included primary cortical neurons, hippocampal neurons, and astrocytes [147-150].

The neuron-like cell line mostly used in previous investigations of microwave radiation bioeffects was the PC12 cell line. The PC12 cell line is derived from rat adrenal pheochromocytoma cells with fast proliferation. They can be induced to generate a neuron-like cell type that has synapses when treated with nerve growth factor (NGF). The PC12 cell line is widely used to study the mechanisms of learning and memory after microwave exposure [36, 37, 67, 77, 151]. Moreover, HT22 cells $[152,153]$ and MN9D cells [154] were also used in studies on the biological effects of microwave radiation.

\section{Germ cells}

There are two main common germ cell types used in studies on the reproductive system of microwave 
radiation. One was the mouse spermatocyte line GC2spd (ts) $[155,156]$, and the other was Sertoli cells [14]. The GC-2spd (ts) cell line derived from the cotransfection of mouse spermatocytes with the simian virus 40 (SV40) large $\mathrm{T}$ antigen gene and a temperature-sensitive mutant of the p53 gene is immortalized. The GC-2spd (ts) cell line expresses the lactate dehydrogenase $\mathrm{C} 4$ isozyme and the cytochrome $c_{t}$ isoform. The GC-2spd (ts) line forms round spermatids [157]. Sertoli cells play a key role in the maintenance of normal spermatogenesis [158].

\section{Heart cells}

As the structural basis of cardiac excitatory contraction function, cardiomyocytes were often used to investigate the effects of microwave radiation on the myocardial cell membrane and intracellular calcium levels [80, 147, 159, 160]. Most studies showed that the intracellular calcium concentration decreased in primary cardiomyocytes exposed to microwave radiation at the frequencies of 2.856 and $9 \mathrm{GHz}[147,159]$, whereas the opposite finding was reported by Wolke et al. [160].

\section{Other organisms}

Microwave radiation injury models are not restricted to the animal species and cell types mentioned above. Many different organisms, including even plants [161, 162], bacteria [163], and viruses [164, 165], have also been implemented to establish microwave radiation injury models, although nonmammalian studies are clearly less directly relevant to human effects.

\section{Methods for the assessment of microwave radiation injuries \\ Methods for the evaluation of functional injuries Brain function injuries}

Numerous studies have reported that microwave radiation might influence brain functions $[38,65,166]$. Various methods were developed to investigate changes in brain function-related behavior, electrophysiological activities and $\mathrm{BBB}$ permeability. The methods used to study the harmful effects on brain functions induced by microwave radiation are described in the following sections.

\section{1) Behavior}

The behavioral methods used in studies on the biological effects induced by microwave radiation mainly focused on evaluating the function of learning and memory, anxiety, locomotor activity, depression, and excitability.

The Morris water maze (MWM), named after its inventor Richard Morris [167], was the most widely used behavioral method for learning and memory evaluation, especially for rodents $[3,4,12,13,15,16,37,40,65,68$, 71, 73, 94, 110-112, 168-170]. In addition, other methods, such as the Y-maze, eight-arm radial maze, and elevated plus maze (EPM), were also used to study the effect induced by microwave exposure on learning and memory $[2,110,112,124,171]$.

The most common methods to assess anxiety behavior induced by microwave exposure were the EPM and open field test (OFT) [71, 168, 172]. The EPM was designed based on the conflict between a rodent's instinct to explore a novel environment and their preference for closed arms. The EPM was widely used in anxiety assays [173]. As a popular behavioral test, the OFT is appropriate for social rodents with small living conditions. The OFT was used to measure anxiety-like behaviors in studies on microwave-radiation-induced injuries [71, 168, 174].

In addition, the behavioral tests commonly used to assess locomotor activities included the OFT [25, 124, 125], rotarod tests [125], and accelerated rotarod systems [124]. Moreover, forced swimming tests (FSTs) [124, 168] and tail suspension tests (TSTs) [168] were implemented to evaluate the level of depression induced by microwave radiation.

\section{2) Electrophysiological activities}

In studies on brain physiological activity changes caused by microwave radiation, the most commonly used methods were electroencephalography (EEG) and in vivo hippocampal long-term potentiation (LTP) recording. EEG could be used to reflect changes in brain function, including sleep quality [70, 166, 175-186]. LTP recording is a well-recognized electrophysiological method used to study synaptic plasticity induced by microwave radiation with respect to learning and memory [13].

\section{3) BBB permeability}

Evans blue (EB) staining was the most popular method used to study the changes in BBB permeability induced by microwave radiation.

Serum albumin is the main serum protein that cannot cross the $\mathrm{BBB}$ under physiological conditions. $\mathrm{EB}$ dye can bind to serum albumin tightly. Therefore, serum albumin can be traced by EB dye when using fluorescence microscopy. When $\mathrm{BBB}$ permeability increases, EB-dye-bound albumin may extravasate through the BBB into extracellular brain tissue [187]. It was reported that more EB dye was observed in brain tissue after microwave exposure [72, 90, 91, 188, 189]. 
In addition, several methods, such as albumin immunohistochemistry staining [89,114-116, 190], transendothelial electrical resistance (TEER) measurement [38], horseradish peroxidase (HRP) staining method [38], and ${ }^{14} \mathrm{C}$-sucrose-tracing methods [148], could also be used to study the effects on BBB permeability induced by microwave radiation. TEER indicates the impedance to pass through the $\mathrm{BBB}$, which is recognized as one of the most accurate and sensitive indicators of BBB integrity [38].

\section{Reproductive function injuries}

It was reported that microwave radiation might cause damage to reproductive functions, such as changes in sex hormone (such as testosterone and estradiol) levels and sperm parameters [7, 19, 191-193]. Enzyme immunoassays [122] and enzyme-linked immunosorbent assays (ELISAs) [19, 193-195] were widely used in studies of sex hormone levels after exposure to microwave radiation. A hemocytometer was implemented to assess spermatozoa motility and count [122, 191, 196]. Eosinnigrosin staining and supra-vital staining could also be used to study sperm viability [122, 191, 192].

\section{Cardiac function injuries}

Many studies showed that microwave radiation might cause cardiac physiological (heart rate, blood pressure, etc.), biochemical (myocardial enzyme, ion concentration, etc.) and endocrine dysfunctions.

The most widely used method for evaluating the effect on cardiac physiological function following microwave radiation was electrocardiography (ECG) [197-199]. Furthermore, photoplethysmography (PPG) sensors and sphygmomanometers could also be used to investigate the effect of microwave radiation on heart rate and blood pressure [106, 200, 201]. Fluorescence was used to measure the changes in cardiac biochemical functioning induced by microwave radiation [79, 147]. Radioimmunoassay was the method of choice to evaluate cardiac endocrine function after exposure to microwave radiation [202].

\section{Endocrine organ function injuries}

There was evidence that microwave exposure might have negative impacts on endocrine organ function, mainly hormone level disorder. Many studies reported that ELISA was the most commonly used method for evaluating the effects of microwave radiation on endocrine organ function $[2,6,193,195,203,204]$.

\section{Methods for the evaluation of structural injuries Microstructural injuries}

With light microscopy, the morphological changes in the microstructure of either animal or cell models after exposure to microwave radiation could be observed using hematoxylin and eosin (HE) staining or special dyeing methods. HE staining is one of the most widespread methods for observing the microstructure of various organs, such as the brain, heart, reproductive organs, and endocrine organs $[3,4,6,12,13,15,19,67$, $73,79,89,92,104,107,121,205,206]$. The function of special dyeing methods is to demonstrate specific cellular components. Special dyeing methods were used to observe changes in specific cellular structures of nerve and testicular tissues in studies of microwave radiation effects [17, 40, 65, 92, 116, 207, 208].

Special dyeing methods used to analyze nerve tissue injury induced by microwave radiation included cresyl violet, toluidine blue, Fluoro-Jade B, Golgi, and Luxol fast blue staining. Cresyl violet and toluidine blue staining were designed to observe Nissl bodies in neurons [17, 116, 207]. De Gannes et al. [116] reported that both cresyl violet staining and Fluoro-Jade B methods indicated the occurrence of dark neurons and neuronal degeneration by observing the states of the Nissl bodies. This study suggested that the latter was a more reliable method of neuronal degeneration evaluation induced by microwave radiation. Golgi staining was used in dendritic spine density examination [40]. Luxol fast blue staining was implemented to observe nerve myelin [92].

The special dyeing method for examining the changes in testicular structure induced by microwave radiation was toluidine blue staining [208]. Toluidine blue staining was used for seminiferous tubule observation, which might be a simple method to observe spermatozoa [208].

\section{Ultramicrostructural injuries}

Electron microscopy, including transmission electron microscopy (TEM) $[3,4,12,13,36,65,67,79,81,104$, $107,209,210]$ and scanning electron microscopy (SEM) [38], was used to observe ultrastructural changes in neurons, germ cells, and cardiomyocytes after microwave radiation.

\section{Methods for the investigation of the biological mechanisms of microwave exposure injuries Apoptosis and abnormal proliferation}

On the one hand, methods for mechanistic studies of microwave-radiation-induced apoptosis mainly included flow cytometry (FCM) [14, 68, 84, 155, 211, 212], in situ end labeling (TUNEL assay) [104, 107, 209, 213, 214], acridine orange/ethidium bromide staining (AO/EB) [14], and Muse cell analysis [79]. On the other hand, the widely used methods to analyze cell proliferation included MTT [155] and immunohistochemical assays [14, $25,40,191,215,216]$. 


\section{Cell membrane damage}

The most commonly used method for the examination of ion channel activities after microwave radiation exposure was the whole-cell patch clamp technique [80]. Moreover, the fluorescence method was one of the most popular methods used to measure the changes in intracellular calcium ion $\left(\mathrm{Ca}^{2+}\right)$ concentration induced by microwave exposure $[67,147,160]$.

\section{Changes in proteins}

Various methods were used in mechanistic studies of microwave-radiation-induced changes in proteins, such as immunoassays, proteomic methods, and nondenaturing polyacrylamide gel electrophoresis (native PAGE).

\section{1) Immunoassays}

Immunoassays based on antigen-antibody reactions are helpful in either qualitative or quantitative analysis of biological samples. The immunoassay methods implemented in the mechanistic studies of microwave radiation mainly included ELISA, Western blotting, immunohistochemistry, immunoprecipitation, and coimmunoprecipitation assays.

ELISA is a classic method for measuring immunoreactions by binding soluble antigens or capturing antibodies on solid carriers [217]. ELISA was used to assess the changes in neurotransmitters, cytokines and protein kinase A (PKA) after microwave radiation exposure [74, 125, 203, 218].

Western blotting is a widely used method in molecular biology, biochemistry, and

immunogenetic studies. Western blotting could be used to measure the levels of protein expression, including stress-related proteins, apoptosis-related proteins, synapse-related proteins, signal transduction molecules, neurotransmitter receptors, etc. [37, $65,73,79,219]$.

Immunohistochemistry methods, such as radioimmunoassay, immunofluorescence, and immune colloidal gold techniques, can provide semiquantitative evaluation of proteins. They have the advantage of pinpointing the given antigen in the tissue. Immunohistochemistry technologies were used to study the biological effects of microwave radiation on neurotransmitter regulation, the stress response, cell proliferation and death regulation, cell membrane damage and signal transduction $[2,125,191,220]$.

Diverse methods, including immunoprecipitation and coimmunoprecipitation, could also be used to evaluate the biological effects of microwave radiation on signal transduction molecules [38].

2) Proteomics method
A proteome is an indication of a protein expression profile. Proteomics analyses compare protein expression levels and assess changes in protein patterns [221]. Proteomics analyses were used to examine the changes in proteins expressed in rat testes after exposure to $900 \mathrm{MHz}$ microwave radiation, and two regulatory proteins, ATP synthase beta subunit and precursor, were found to be upregulated [222].

\section{3) Native PAGE}

Native PAGE is both a qualitative measurement method and a protein separation and purification technique. Native PAGE maintains the activities of proteins without the addition of denaturants, such as sodium dodecyl benzene sulfonate or mercaptoethanol. Native PAGE combined with a spectrophotometric method was used to determine the activities of antioxidant enzymes after microwave radiation [41].

\section{Changes in genes and gene expression}

Gene evaluation methods used in biological mechanism studies of microwave radiation mainly include polymerase chain reaction (PCR), in situ hybridization (ISH), comet assays, electrophoretic mobility shift assays (EMSAs), DNA sequencing and genotyping methods.

PCR methods, such as real-time PCR and reverse transcription PCR (RT-PCR), have been widely used to investigate the effect of microwave radiation on the expression of genes involved in the stress response, signal transduction pathways, apoptosis, neurotransmitter receptors, cytokines, tight junction proteins, and restriction fragment length polymorphism (RFLP) analysis [14, $17,18,38,68,223,224]$.

ISH was used to determine the expression of stressrelated genes such as heat shock protein (HSP) 70 and c-fos mRNAs [225]. The comet assay is widely used to assess DNA damage [97, 191, 226]. EMSA was a technique used to investigate the interaction of DNAbinding proteins and their sequences. EMSA was used to examine the binding activities of a transcription factor and DNA after microwave exposure [68]. DNA sequencing was used to assess the variation in the promoter region of the $2 \mathrm{~B}$ subunit of the $\mathrm{N}$-methyl-D-aspartate receptor (NR2B) gene and analyze the relationships between brain damage and NR2B gene polymorphisms caused by microwave radiation [68].

Furthermore, both flow cytometry and confocal microscopy were used to assess the occurrence of micronuclei induced by microwave exposure [227].

\section{Changes in oxidative stress parameters}

The most popular methods for evaluating oxidative stress-related indicators after microwave radiation 
included colorimetry and electron spin resonance (ESR) technology.

Based on a reaction producing a colored substance, the colorimetric method is designed to analyze the contents of an unknown sample by measuring its color depth. In previous studies on the biological mechanism of microwave radiation, colorimetry was used to measure the level of malondialdehyde (MDA), total antioxidant status (TAS), total antioxidative capacity (TAC), and total oxidant status (TOS) $[97,216]$. ESR is designed to determine the interactions between unpaired electrons and the environment. ESR was used to measure the rates of superoxide and nitrogen oxide generation caused by microwave radiation [23].

\section{Changes in neurotransmitters}

The most commonly used method in the measurement of neurotransmitters is high-performance liquid chromatography (HPLC). The development of HPLC is due to the introduction of the gas chromatography theory on the basis of classic liquid chromatography. In previous studies on the biological effects of microwave radiation, HPLC was widely used to measure the level of neurotransmitters such as aspartic acid (Asp), glutamate (Glu), glycine (Gly), and gamma-aminobutyric acid (GABA) [3, $12,36,67,68,73,92,124,228]$.

\section{Indicators of microwave radiation-induced biological injuries \\ Indicators of functional injuries \\ Indicators of brain function injuries}

\section{1) Behavior}

Behavioral indicators are frequently used to examine microwave radiation-induced abnormalities in brain functions, including learning and memory, anxiety, depression, and locomotor activity. Learning and memory, one of the most important cognitive functions, are hotspots in the field of microwave-radiation-induced biological effects. The most common behavioral indicators of learning and memory were swimming speed, average escape latency (AEL), the percentage of time spent in the target quadrant and average crossing times of the MWM, and the time to enter one of the closed arms of the EPM $[3,4,12,13,15,16,37,40,65,68$, $71,73,94,110-112,168,169]$. Moreover, the behavioral indicators for the evaluation of anxiety and depression included the total distance traveled, the frequency of entries into and the duration of time spent in the center zone, the number of entries into all zones, the time spent in the periphery of the open field of the OFT, the percent frequency of entering the open arms, the percentage of time spent in the open arms of the EPM, and the immobility time on the TST and FST $[71,168]$. The common behavioral indicators of locomotor activity mainly included the scores for the moving distance, moving duration and rearing frequency of the OFT [125]. Previous studies showed that microwave radiation might negatively affect the learning and memory [2, $3,65]$, anxiety, depression [168], and locomotor activity [125] of experimental animals. However, some studies reported that microwave radiation had no significant effect on learning and memory, anxiety, or depression [124].

2) EEG

EEG can be used to depict the electrical activity of neurons in the brain. An encephalogram macroscopically indicates changes in brain function. In previous studies on the biological effects of microwave radiation, the indicators provided by an EEG mainly included spectral bands, gravity frequency, and power spectra [3, 4]. Hao et al. [3] reported that the power of $\alpha$ and $\delta$ waves of Wistar rats decreased and the power of $\theta$ waves increased after exposure to microwave radiation at an average power density of $30 \mathrm{~mW} / \mathrm{cm}^{2}$ and a SAR value of $10.5 \mathrm{~W} / \mathrm{kg}$ for $15 \mathrm{~min}$ per day, once every other day three times, which implied a perturbation in encephalogram activity.

3) LTP

As a classic model designed for studies on learning and memory, LTP indicates the state of synaptic plasticity. The most popular indicator of LTP used in microwave radiation effect studies was the amplitude of population spikes (PSs) [13]. Wang et al. [13] reported a decrease in the amplitude of PSs in rats after microwave radiation exposure, which suggested defects in LTP induction and impairments in learning and memory.

\section{4) BBB permeability}

Indicators used to depict $\mathrm{BBB}$ permeability in studies on microwave radiation biological effects included the presence of endogenous albumin in the brain $[89,114-116]$; the expression of zonula occludens-1 (ZO-1) [38, 148], occludin [38], and glial fibrillary acidic protein (GFAP) [96, 148, 225]; TEER values [38], and the permeability coefficient of HRP [38]. The presence of endogenous albumin in the brain was the primary indicator used. ZO-1 and occludin are endothelial tight junction (TJ) proteins. The reduced expression of $\mathrm{ZO}-1$ can disrupt $\mathrm{TJ}$ proteins and cause BBB breakdown. Tyrosine phosphorylation of occludin triggers BBB dysfunction [229]. GFAP, a marker of mature astrocytes, has been indicated to be responsible for maintaining astrocytic structure and shape [230]. The increased 
expression of GFAP indicates reactive astrocytes and brain injury [231]. A series of studies reported that microwave radiation might induce decreased expression of ZO-1 and occludin, enhanced tyrosine phosphorylation of occludin, and increased expression of GFAP in the brain $[38,96]$.

In previous studies, it was found that $\mathrm{BBB}$ permeability increased after microwave radiation exposure $[38,114]$. However, one study using headonly exposure of rats to the GSM-900 signal for $2 \mathrm{~h}$ showed no effect on BBB permeability [116].

\section{Indicators of reproductive function injuries}

The common indicators used in evaluations of reproductive function after microwave radiation included the level of testosterone, the level of estradiol, and sperm parameters (such as epididymal sperm motility, sperm concentration, vitality, sperm count, and the percentage of morphologically abnormal spermatozoa) [19, 191-193]. Recently, the available evidence was presented suggesting that microwave radiation exposure might have deleterious effects on the reproductive function of rats, e.g., decreased levels of serum testosterone; increased levels of estradiol; decreased sperm count, viability and motility; and increased sperm deformities [19, 191].

\section{Indicators of cardiac function injuries}

Previous studies showed that cardiac physiology, biochemistry and endocrine function can be adversely affected after microwave radiation.

The major indicators of cardiac physiological function implemented in studies of biological injuries induced by microwave radiation included heart rate, blood pressure and ECG [166, 198, 199, 232, 233]. It is well known that compensatory changes in blood pressure and heart rate occur in pathological processes. ECG indicators such as arrhythmia, heart block and myocardial infarction could be used in the diagnosis of heart diseases. Common blood pressure indicators used in studies on microwave biological effects included systolic blood pressure (SBP) and diastolic blood pressure (DBP) [232]. ECG indicators used in the studies on the biological effects of microwave radiation mainly included the time intervals between consecutive $\mathrm{R}$ waves and autonomic indices in both the time and the frequency domains, which depicted the measurement of the heart rate variability (HRV) $[5,166$, 197, 198, 234-238].

Cardiac biochemical function indicators used in the studies of microwave-radiation-induced biological injuries mainly included myocardial enzyme spectrum levels and ion concentrations. It is well known that the activities of myocardial enzymes and intracellular or extracellular ion concentrations change when cardiomyocytes are injured and the integrity of the cell membrane is broken. The indicators of the myocardial enzyme spectrum used in previous studies of microwaveradiation-induced cardiac injuries mainly included the levels of lactate dehydrogenase (LDH), creatine kinase (CK), creatine kinase-MB (CK-MB) and hydroxybutyrate dehydrogenase (HBDH) [79, 205, 239]. The most commonly used indicator of ion concentration was the $\mathrm{Ca}^{2+}$ level of ventricular myocytes [80].

The heart can secrete various peptide hormones to regulate its own function. Therefore, the expression of these hormones could also be used to evaluate the state of cardiac endocrine function. The most popular indicator used in studies of microwave-radiation-induced cardiac injury is atrial natriuretic peptide (ANP) [8].

\section{Indicators of endocrine organ function injuries}

The indicators of endocrine organ function used in studies of injuries induced by microwave radiation mainly included the levels of plasma adrenocorticotropin hormone $(\mathrm{ACTH})$, growth hormone $(\mathrm{GH})$, cortisol $(\mathrm{CS})$, corticosterone (CORT) and thyroid hormone $(\mathrm{TH})[2,6$, $145,172,195,204,240]$. ACTH and GH produced in the pars distalis of the adenohypophysis are involved in various pathophysiological processes, which are closely connected with the stress response. CS secreted by the zona fasciculata cells of the adrenal gland is a glucocorticoid with anti-inflammatory properties. The changes in TH induced by microwave radiation included changes in thyroxine (T4) and triiodothyronine (T3), which are synthesized by thyroid follicular epithelial cells and help to promote the development of the central nervous system (CNS) and metabolic function.

\section{Indicators of structural injuries}

Indicators of brain structural injuries after microwave radiation mainly included cytological changes in neuronal components, such as the morphology of neurons, nuclei, cytoplasm (mitochondria, endoplasmic reticulum, etc.) and synapses. Increased numbers of degenerating neurons and stained nuclei and cytoplasm in the hippocampus were observed by light microscopy after exposure to microwave radiation $[3,12,13,15,67,71,73$, 121]. Changes in the cytoplasm in hippocampal neurons (mitochondria swelling and endoplasmic reticulum dilation) and synaptic structure (decreased density of synaptic vesicles, blurred synaptic gaps, and decreased postsynaptic density (PSD) length) were observed by electron microscopy $[3,65,125]$.

The indicators used in the studies of structural damage of reproductive tissue induced by microwave radiation included the number of spermatogenic cells, the morphologies and diameter of seminiferous tubules, the thickness of the seminiferous epithelium and Leydig cells in testes, the diameter of the epididymis, and the height of 
the epithelium, the number of ovarian follicles $[7,19,88$, 191]. Azadi Oskouyi et al. [7] reported decreased epithelial height and diameter of the epididymis in New Zealand rabbits exposed to $950 \mathrm{MHz}$ microwave radiation for $2 \mathrm{~h} / \mathrm{d}$ for 2 weeks at an output power of 3 or 6 watts.

The indicators used in the studies on cardiac tissue structural effects induced by microwave radiation mainly included the morphology of cell nuclei and cytoplasm (mitochondria, glycogen granules and lipid droplets), the area fraction percentage of nonfibrotic myocardium, and the arrangement of myocardial fibers [8, 79, 107, 205]. Numerous histological results have indicated that microwave radiation might cause structural impairment in the heart, showing disordered muscle fibers, nuclear pyknosis, cytoplasmic vacuolization, myofilament impairment and reduction, decreased mitochondrion numbers, etc. $[79,107]$.

The indicators used in the studies of structural damage of endocrine tissue induced by microwave radiation included the thickness of the zona fasciculata (ZF), the cell size and perimeter of the $\mathrm{ZF}$, and the columnar organization of ZF cells in the adrenal glands [6]. Shahabi et al. [6] reported that the fasciculata layer of the adrenal cortex thickened, the number of ZF cells was constant, and the ZF cell size and perimeter increased when Wistar rats were exposed to mobile radiofrequency $(900 \mathrm{MHz})$ for $6 \mathrm{~h} / \mathrm{d}$ for $4 \sim 8$ weeks at a SAR of $1.010 \mathrm{~W} / \mathrm{kg}$.

\section{Indicators for investigations of the mechanism of biological injury \\ Neurotransmitters}

The indicators involved in the studies of changes in neurotransmitters after microwave exposure mainly included amino acid neurotransmitters, choline neurotransmitters, catecholamine neurotransmitters, and their markers.

Amino acid neurotransmitters used in biological injury studies of microwave radiation mainly included inhibitory transmitters (GABA, Gly) and excitatory transmitters (Glu, Asp) [3, 12, 36, 37, 67, 68, 73, 124]. Choline neurotransmitters and their markers, such as acetylcholine (Ach), cholinesterase (ChE), and choline acetyl transferase (ChAT), were implemented in previous studies $[239,241]$. Catecholamine neurotransmitters and their markers included dopamine (DA), noradrenaline (NA), serotonin (5-HT), tyrosine hydroxylase (TH), tryptophan hydroxylase (TPH), monoamine oxidase (MAO), and 3,4-dihydroxyphenylacetic acid (DOPAC), which were used in studies on the mechanism of brain injury induced by microwave radiation $[18,73,92,124,125$, $203,204,228]$. However, there are still some controversies regarding the effects of microwave radiation on neurotransmitters. Some scientists argued that microwave radiation might irregularly alter the level of neurotransmitters in the brain $[3,68,125,241]$, whereas others did not find any changes [124].

\section{Metabolic indicators}

The metabolic indicators used in the studies of microwave-radiation-induced injuries mainly included ATP metabolism indicators (adenosine triphosphate (ATP), and CK) and mitochondrial function damage indicators (mitochondrial respiratory chain complexes I IV, cytochrome oxidase (CO), etc.) $[40,79,206,242-$ 244]. A series of studies demonstrated that energy metabolism disorders might be a cause of the adverse biological effect of microwave radiation, i.e., a significant decrease in the activities of $\mathrm{CO}$, mitochondrial respiratory chain complexes I - IV and CK and the level of ATP $[40,79,242]$.

\section{Stress-related indicators}

Stress-related indicators used in the studies of microwave radiation-induced injury mainly included all oxidative stress indicators, HSP70 levels, immediate early genes (such as c-fos and c-jun) and their protein levels, and endoplasmic reticulum stress indicators.

Oxidative stress, one of the most important mechanisms of microwave radiation-induced biological injuries, has been considered a result of the imbalance between pro-oxidant and antioxidant systems [19]. The common indicators implemented to examine oxidative stress included 1) free radicals (such as reactive oxygen species [ROS], nitric oxide [NO], and superoxide) [23, $40,41,156,211,226,227,245], 2)$ antioxidant indicators (enzymes such as superoxide dismutase [SOD], catalase $[\mathrm{CAT}]$, glutathione peroxidase [GSH-px], and nonenzymes [such as glutathione [246], TAC, TAS, and TOS] $[17,19,97,191,209,247]$, and 3) oxidation products (such as MDA, conjugated dienes, protein carbonyl [PCO] and 8-hydroxydeoxyguanosine [8-OHdG]) [17, $45,97,191,247]$. A few reports indicated that free radicals might have adverse effects on cells and increase the oxidation of DNA bases, lipids, and proteins after microwave exposure [17, 45, 97, 191].

HSP70, a molecular chaperone, protects cells from various environmental stresses. The level of HSP70 was used to indicate the change in intracellular stress [110]. A series of studies demonstrated that microwave radiation with frequencies ranging from $900 \mathrm{MHz}$ to 2450 $\mathrm{MHz}$ and power densities ranging from $50 \mathrm{~mW} / \mathrm{cm}^{2}$ to $200 \mathrm{~mW} / \mathrm{cm}^{2}$ could cause an increase in HSP70 levels in rat brain tissue, cardiomyocytes and chick embryos [110, 111, 206, 248].

The c-fos gene related to cell damage and even cell death can be induced to be expressed under nonpathogenic environmental conditions [225]. The morphological 
expression of c-fos is a biomarker of neuronal activation [220, 225]. Additionally, c-jun can be easily induced to be expressed under pathological conditions [225]. Several studies have reported increased expression of c-fos and decreased expression of c-jun in rat brains after exposure to microwave radiation [220, 225].

The indicators of endoplasmic reticulum stress used in studies of microwave radiation bioeffects mainly included the transcription factors XBP1, ATF4 and CHOP $[224,249]$. A recent study showed that microwave radiation at frequencies between $900 \mathrm{MHz}$ and $2450 \mathrm{MHz}$ could decrease the expression of XBP1 splicing mRNA and increase the expression of ATF4 and CHOP mRNA in rat brains, suggesting the activation of endoplasmic reticulum stress [224].

\section{Cell proliferation- and cell death-related indicators}

The most popular indicators used in the studies of cell proliferation and cell death induced by microwave radiation were those involved in autophagy, apoptosis, inflammatory response and cell proliferation.

The commonly used autophagy indicators to evaluate the injuries of microwave radiation included microtubule-associated protein light chain 3 (LC3), the protein expression of autophagy-related gene (ATG) and lysosomal associated membrane protein 1 (LAMP1), and the ratio of LC3-II to LC3-I [3, 250, 251]. Although a series of studies were conducted focusing on autophagy and the biological effects of microwave radiation, the role of autophagy remains unclear.

The apoptosis-related indicators used in the studies of injuries of microwave radiation included $\mathrm{Bcl}-2$ family proteins (such as the anti-apoptotic factor $\mathrm{Bcl}-2$ and the pro-apoptotic factor Bax), apoptosis initiation factors (such as cytochrome C [Cyto C]), caspase family proteins (such as the apoptotic initiator caspase-9 and the apoptotic executor caspase-3), apoptosis rate, and proapoptotic gene p53 [14, 17, 40, 79, 191, 206, 215, 216, 227, 245].

The inflammatory-response-related indicators used in studies of injuries caused by microwave radiation included inflammatory cytokines, such as interleukin (IL)1, IL-2, IL-6, IL-10, IL-12, tumor necrosis factor- $\alpha$ (TNF- $\alpha$ ) and interferon- $\gamma$ (IFN- $\gamma)[45,218,223]$, and inflammatory genes, such as nuclear factor-kappa B (NFкB) $[191,223]$. The weight of evidence from studies on the inflammatory response supports the conclusion that inflammatory effects, including the increased expression of proinflammatory cytokines and the activated inflammatory pathway, might be a potential mechanism of injuries induced by microwave radiation [45, 218, 223].

The cell proliferation-related indicators commonly used in previous studies of microwave radiation injury effects included nucleoprotein Ki-67 and histone kinase
[25, 211, 252]. Ki-67, as an endogenous marker of proliferation, was used to label proliferating cells [25]. The activity of histone kinase related to the $G_{2} / M$ phase transition in the cell cycle is increased in exponentially growing cells [211]. A few studies reported that the number of Ki-67-positive cells and the activity of histone kinase were decreased significantly after microwave exposure $[25,211,252]$.

\section{Indicators-related to cell membrane damage}

The major indicators related to cell membrane damage that were implemented in the studies of injuries induced by microwave radiation included intracellular and extracellular ion concentrations, ion channel activity, and membrane receptor expression levels.

Changes in intracellular and extracellular ion concentrations can be used to depict the impairment of ion channels of the cell membrane and changes in cell membrane permeability. Intracellular $\mathrm{Ca}^{2+}$ is one of the most important ions for biological studies of microwave radiation and executes many biological processes [147]. A recent study reported that the levels of total calcium, endoplasmic reticulum calcium and mitochondrial calcium decreased after primary hippocampal neurons were exposed to $2.856 \mathrm{GHz}$ pulsed microwave radiation, suggesting calcium efflux during microwave radiation exposure [147].

The activity of voltage-gated calcium channels (VGCCs) was used in previous studies as an indicator of microwave-radiation induced changes in ion channels [80, 253]. Olgar et al. [80] found that although the Ltype $\mathrm{Ca}^{2+}$ current $\left(\mathrm{I}_{\mathrm{CaL}}\right)$ values in cardiomyocytes were not altered after exposure to $2.1 \mathrm{GHz}$ microwave radiation, the isoproterenol-induced $\mathrm{I}_{\mathrm{CaL}}$ response was strikingly reduced.

The expression levels of $\mathrm{N}$-methyl-D-aspartate receptor (NMDAR), $\beta_{1}$-adrenergic receptor $\left(\beta_{1}\right.$-AR) and muscarinic type 2 acetylcholine receptor (M2-AChR) in the heart $[12,67,254]$ have been used to evaluate the changes in cell membrane receptors induced by microwave radiation. It has shown that the expression levels of NMDARs at the postsynaptic membranes were related to excitatory synaptic transmission and synaptic plasticity [67]. The expression levels of $\beta_{1}$-AR and M2AChR were used to assess heart function [254].

Other membrane properties, such as the function of the synaptic vesicular membrane, can be indicated by the expression level of synaptic vesicular-associated proteins and the level of neurotransmitters [37, 69].

\section{Signal transduction-related indicators}

The signal-transduction-related indicators implemented in the studies on biological effects induced by microwave radiation mainly included 1) NMDAR-related signaling 
pathway molecules (such as the key NMDAR subunits, calmodulin-dependent protein kinase II [CaMKII], cyclic adenosine monophosphate [cAMP] responsive elementbinding [CREB], postsynaptic density protein-95 [PSD95], PKA and the p44/42 mitogen activated protein kinase [p44/42 MAPK]) $[4,12,36,67,68,74], 2)$ proteins of the protein kinase $\mathrm{C}(\mathrm{PKC})$ signaling pathway $[84,245$, $255]$, 3) proteins of the signaling pathways associated with the activation of MAPK signaling cascades (such as extracellular signal-regulated kinases [ERK], c-jun amino-terminal kinases [JNK] and p38MAPK) [79, 227], and 4) proteins of the NO signaling pathway [80].

NMDAR-related signaling pathways are mainly involved in studies on the impairment of learning and memory function induced by microwave radiation $[4,12$, 36, 67]. The activation of molecules in NMDAR-related signaling pathways has been suggested to be closely related to synaptic plasticity [12].

PKC is commonly used in biological studies of the effects of microwave radiation on the brain and male infertility [84, 245, 255]. PKC plays a critical role in cell signaling pathways to regulate cell proliferation, death, and stress. Studies have revealed that the decreased level of PKC in the brain and sperm cells might trigger an overproduction of ROS and subsequently cause injury after exposure [84, 245, 255].

It has been well established that MAPK cascades are responsible for regulating oxidative stress [79, 227]. Several studies found that microwave radiation might exert detrimental effects on the heart and brain through oxidative stress, which activates MAPK cascades [79, 227].

A study suggested that an upregulated NO signaling pathway might trigger a reduction in the $\beta$-adrenergic $(\beta-A R)$ response of ventricular myocytes after microwave radiation exposure [80]. This was induced by modulating a second messenger, i.e., cyclic guanosine monophosphate (cGMP) [80].

\section{Genotoxicity-related indicators}

There are controversies regarding the genotoxic effects induced by microwave radiation exposure. Most studies have suggested that microwave radiation causes genotoxic effects [23, 97, 227, 256], while others have drawn different conclusions [257]. The genotoxicity-related indicators used in the studies of microwave radiation injury mainly included DNA single- or double-stranded breaks and micronuclei $[23,97,227,256]$.

\section{Discussion}

In this review, we combined previous studies on microwave radiation biological effects to summarize the main factors that are essential for the establishment of a microwave radiation injury model: microwave exposure conditions, subjects used to establish injury models, and methods and indicators used to assess the establishment of injury models. The establishment of an injury model is the premise of studies on the biological effects of microwave radiation. The establishment of an injury model is important to both the reliability and the reproducibility of these studies, although the reproducibility may also be influenced by the funding sources of specific studies [54, 258]. Although fruitful results have been achieved, further research on the biological injuries induced by microwave radiation is an inevitable development trend.

First, 1) to establish a certain microwave radiation injury model (e.g., for the purpose of investigating the mechanisms of MW-induced bioeffects), a specified standardized microwave exposure procedure should be performed, which will be beneficial to comparative analyses of the results from different laboratories, although replication does not fail if the methodology is exactly the same as in previous studies. 2), to investigate the bioeffects induced by real-world microwave radiation, the exposure procedures should capture the complexity and diversity of real-world exposure conditions.

Second, although various kinds of subjects have been used to establish biological injury models of microwave radiation, hardly any uniform animal species and cell types are widely used in studies of the biological effects after microwave exposure. In addition, based on the sensitive biological indicators from previous studies, it is important to cultivate novel animal species and cell types sensitive to microwave radiation by transgenic technology.

Third, the choice of methods contributes to screening biological indicators with high sensitivity and specificity for microwave radiation-induced injuries. The methods used in studying the biological effects of microwave radiation rely on the development of science and technology. Appropriate techniques can facilitate studies on the biological effects caused by microwave radiation. In fact, to the best of our knowledge, most of the methods used in present studies cannot demonstrate the real-time biological changes induced by microwave radiation. In the future, the development of more in vivo methods will help us to screen more reliable and sensitive indicators.

Finally, there is a lack of recognized sensitive indicators of biological injuries caused by microwave radiation. Therefore, it is helpful to screen and verify the sensitive indicators provided by previous studies. This may create a new opportunity for diagnosis and therapeutic intervention. In the future, quantitative biomarkers should be further explored, which will lay a foundation for building a reliable dose-effect relationship of biological effects induced by microwave radiation. 


\section{Conclusion}

In summary, we reviewed the microwave exposure conditions, subjects used to establish injury models, and common methods and indicators used to establish injury models of microwave radiation. This work may be helpful for further studies of biological effects induced by microwave radiation.

\section{Abbreviations}

5-HT: Serotonin; 8-OHdG: 8-Hydroxydeoxyguanosine; Ach: Acetylcholine; Asp: Aspartic acid; ACTH: Adrenocorticotropin hormone; AEL: Average escape latency; ANP: Atrial natriuretic peptide; AO/EB: Acridine orange/ethidium bromide; ATG: Autophagy-related gene; ATP: Adenosine triphosphate; BBB: Blood-brain barrier; DBP: Diastolic blood pressure; BPS: Blood pressure; CAMP: Cyclic adenosine monophosphate; cGMP: Cyclic guanosine monophosphate; $\mathrm{Ca}^{2+}$ : Calcium ion; CaMKIl: Calmodulin-dependent protein kinase II; ChAT: Choline acetyl transferase; ChE: Cholinesterase; Cyto C: Cytochrome C; CAT: Catalase; CK: Creatine kinase; CK-MB: Creatine kinaseMB; CNS: Central nervous system; CO: Cytochrome oxidase; CORT: Corticosterone; CREB: Cyclic adenosine monophosphate responsive element-binding; CS: Cortisol; CW: Continuous wave; DA: Dopamine; DOPAC: 3,4-Dihydroxyphenylacetic acid; EB: Evans blue;

ECG: Electrocardiography; ELISA: Enzyme-linked immunosorbent assay; EMSA: Electrophoretic mobility shift assay; EPM: Elevated plus maze; ERK: Extracellular signal-regulated kinases; ESR: Electron spin resonance; FCM: Flow cytometry; FST: Forced swimming test; Glu: Glutamate; Gly: Glycine; GABA: Gamma-aminobutyric acid; GFAP: Glial fibrillary acidic protein; GH: Growth hormone; GSH: Glutathione; GSH-px: Glutathione peroxidase: GSM: Global System for Mobile Communication: $\mathrm{HBDH}$ : Hydroxybutyrate dehydrogenase; HE staining: Hematoxylin and eosin staining: HPLC: High-performance liquid chromatography; HRP: Horseradish peroxidase; HRV: Heart rate variability; HSP: Heat shock proteins; ICaL: L-type $\mathrm{Ca}^{2+}$ currents; IFN-y: Interferon- $\gamma$; IL: Interleukin; ISH: In situ hybridization; JNK: c-jun amino-terminal kinases; LAMP1: Lysosomal associated membrane protein 1; LC3: Microtubule-associated protein light chain 3; LDH: Lactate dehydrogenase; LTP: Long-term potentiation; M2-AChR: Muscarinic type 2 acetylcholine receptor; MAO: Monoamine oxidase; MDA: Malondialdehyde; MWM: Morris water maze; native PAGE: Nondenaturing polyacrylamide gel electrophoresis; NA: Noradrenaline; NF-kB: Nuclear factor-kappa B; NGF: Nerve growth factor; NMDAR: N-methyl-D-aspartate receptor; NO: Nitric oxide; NR2B: 2B subunit of N-methyl-D-aspartate receptor; OFT: Open field test; p44/42 MAPK: p44/42 mitogen activated protein kinase: PCO: Protein carbonyl; PCR: Polymerase chain reaction; PKA: Protein kinase A; PKC: Protein kinase C; PPG: Photoplethysmography; PS: Population spike;

PSD: Postsynaptic density; PSD-95: Postsynaptic density protein-95; PW: Pulsed wave; RFLP: Restriction fragment length polymorphism; ROS: Reactive oxygen species; RT-PCR: Reverse transcription PCR; SAR: Specific absorption rate; SD rats: Sprague-Dawley rats; SEM: Scanning electron microscopy; SOD: Superoxide dismutase; SV40: Simian virus 40; $\mathrm{T}_{3}$ : Triiodothyronine; $\mathrm{T}_{4}$ : Thyroxine; TAC: Total antioxidative capacity; TAS: Total antioxidant status; TEER: Transendothelial electrical resistance: TEM: Transmission electron microscopy; TH: Thyroid hormone; TH: Tyrosine hydroxylase; TJ: Tight junction; TNF-a: Tumor necrosis factor-a; TOS: Total oxidant status; TPH: Tryptophan hydroxylase; TST: Tail suspension test; TUNEL: In situ end labeling; VGCCs: Voltage-gated calcium channels; WHO: World Health Organization; ZF: Zona fasciculata; ZO-1: Zonula occludens-1; $\beta$-AR response: $\beta$-adrenergic response; $\beta_{1}$-AR: $\beta_{1}$-adrenergic receptor

\section{Acknowledgments}

Not applicable.

\section{Authors' contributions}

YFL wrote the paper and outlined this manuscript. HYW and RYP provided detailed guidance on this article and edited the manuscript. All authors read and approved the final manuscript.

\section{Funding}

This work was supported by the National Natural Science Foundation of China (61801506)

Availability of data and materials

Not applicable.

Ethics approval and consent to participate

Not applicable.

\section{Consent for publication}

Not applicable.

\section{Competing interests}

The authors declare that they have no competing interests.

Received: 14 June 2020 Accepted: 29 January 2021

Published online: 18 February 2021

\section{References}

1. The World Health Organization. 2020. https://www.who.int/health-topics/ electromagnetic-fields\#tab =tab_ 1 .

2. Shahin S, Banerjee S, Swarup V, Singh SP, Chaturvedi CM. 2.45-GHz microwave radiation impairs hippocampal learning and spatial memory: Involvement of local stress mechanism-induced suppression of iGluR/ERK CREB signaling. Toxicol Sci. 2018;161:349-74.

3. Hao YH, Li WC, Wang H, Zhang J, Yu C, Tan SZ, et al. Autophagy mediates the degradation of synaptic vesicles: A potential mechanism of synaptic plasticity injury induced by microwave exposure in rats. Physiol Behav. 2018; 188:119-27.

4. Wang H, Tan SZ, Xu XP, Zhao L, Zhang J, Yao BW, et al. Long term impairment of cognitive functions and alterations of NMDAR subunits after continuous microwave exposure. Physiol Behav. 2017;181:1-9.

5. Ekici B, Tanındı A, Ekici G, Diker E. The effects of the duration of mobile phone use on heart rate variability parameters in healthy subjects. Anatol J Cardiol. 2016;16(11):833-8.

6. Shahabi S, Hassanzadeh Taji I, Hoseinnezhaddarzi M, Mousavi F, Shirchi S, Nazari A, et al. Exposure to cell phone radiofrequency changes corticotrophin hormone levels and histology of the brain and adrenal glands in male Wistar rat. Iran J Basic Med Sci. 2018;21:1269-74.

7. Azadi Oskouyi E, Rajaei F, Safari Variani A, Sarokhani MR, Javadi A. Effects of microwaves (950 MHz mobile phone) on morphometric and apoptotic changes of rabbit epididymis. Andrologia. 2015;47:700-5.

8. Ye W, Wang F, Zhang W, Fang N, Zhao W, Wang J. Effect of mobile phone radiation on cardiovascular development of chick embryo. Anat Histol Embryol. 2016;45:197-208.

9. Castillo M, Quencer RM. Sublethal exposure to microwave radar. JAMA. 1988;259(3):355.

10. Zhi WJ, Wang LF, Hu XJ. Recent advances in the effects of microwave radiation on brains. Mil Med Res. 2017;4:29.

11. Tan SZ, Wang H, Xu XP, Zhao L, Zhang J, Dong J, et al. Study on dosedependent, frequency-dependent, and accumulative effects of $1.5 \mathrm{GHz}$ and $2.856 \mathrm{GHz}$ microwave on cognitive functions in Wistar rats. Sci Rep. 2017; 7(1):10781.

12. Wang H, Peng RY, Zhao L, Wang SM, Gao YB, Wang LF, et al. The relationship between NMDA receptors and microwave-induced learning and memory impairment: A long-term observation on Wistar rats. Int J Radiat Biol. 2015:91(3):262-9.

13. Wang H, Peng RY, Zhou HM, Wang SM, Gao YB, Wang LF, et al. Impairment of long-term potentiation induction is essential for the disruption of spatial memory after microwave exposure. Int J Radiat Biol. 2013;89(12):1100-7.

14. Wu H, Wang D, Shu Z, Zhou H, Zuo H, Wang S, et al. Cytokines produced by microwave-radiated Sertoli cells interfere with spermatogenesis in rat testis. Andrologia. 2012;44(Suppl 1):590-9.

15. Sharma A, Kesari KK, Saxena VK, Sisodia R. Ten gigahertz microwave radiation impairs spatial memory, enzymes activity, and histopathology of developing mice brain. Mol Cell Biochem. 2017:435(1-2):1-13.

16. Sharma A, Sisodia R, Bhatnagar D, Saxena VK. Spatial memory and learning performance and its relationship to protein synthesis of Swiss albino mice exposed to $10 \mathrm{GHz}$ microwaves. Int J Radiat Biol. 2014;90(1):29-35. 
17. Motawi TK, Darwish HA, Moustafa YM, Labib MM. Biochemical modifications and neuronal damage in brain of young and adult rats after long-term exposure to mobile phone radiations. Cell Biochem Biophys. 2014;70(2):84555.

18. Megha K, Deshmukh PS, Ravi AK, Tripathi AK, Abegaonkar MP, Banerjee BD. Effect of low-intensity microwave radiation on monoamine neurotransmitters and their key regulating enzymes in rat brain. Cel Biochem Biophys. 2015;73(1):93-100.

19. Yahyazadeh A, Altunkaynak BZ. Protective effects of luteolin on rat testis following exposure to $900 \mathrm{MHz}$ electromagnetic field. Biotech Histochem. 2019;94(4):298-307.

20. Kaya FA, Dasdag S, Kaya CA, Akdag MZ, Yavuz I, Kilinc N, et al. Effects of radiofrequency radiation by $900 \mathrm{MHz}$ mobile phone on periodontal tissues and teeth in rats. J Anim Vet Adv. 2008;7(12):1644-50.

21. Finnie JW, Blumbergs PC, Cai Z, Manavis J. Expression of the water channel protein, aquaporin-4, in mouse brains exposed to mobile telephone radiofrequency fields. Pathology. 2009;41(5):473-5.

22. Ozgur E, Guler G, Kismali G, Seyhan N. Mobile phone radiation alters proliferation of hepatocarcinoma cells. Cell Biochem Biophys. 2014;70(2): 983-91.

23. Yakymenko I, Burlaka A, Tsybulin I, Brieieva I, Buchynska L, Tsehmistrenko I, et al. Oxidative and mutagenic effects of low intensity GSM $1800 \mathrm{MHz}$ microwave radiation. Exp Oncol. 2018;40:282-7.

24. Koca O, Gokce AM, Ozturk MI, Ercan F, Yurdakul N, Karaman MI. Effects of intensive cell phone (Philips Genic 900) use on the rat kidney tissue. Urol J. 2013;10(2):886-91.

25. Raček A, Beňová K, Arnoul P, Závodská M, Angelidis A, Cigánková V, et al. Age-dependent effect of long-term microwave radiation on postnatal neurogenesis in rats: Morphological and behavioral study. Physiol Res. 2018; 67(3):495-503.

26. Lu ST, Michaelson SM, Pettit S. Increased serum enzyme activity in microwave-exposed rats. Radiat Res. 1983;96(1):152-9.

27. Gary NE, Westerdahl BB. Flight, orientation, and homing abilities of honeybees following exposure to $2.45-\mathrm{GHZ}$ CW microwaves. Bioelectromagnetics. 1981;2(1):71-5.

28. Clark MW, Gildersleeve RP, Thaxton JP, Parkhurst CR, McRee DI. Leukocyte numbers in hemorrhaged Japanese quail after microwave irradiation in ovo. Comp Biochem Phys A. 1987;87(4):923-32.

29. Saito K, Saiga T, Suzuki K. Reversible irritative effect of acute $2.45 \mathrm{GHz}$ microwave exposure on rabbit eyes: A preliminary evaluation. J Toxicol Sci. 1998;23(3):197-203.

30. Rugh $\mathrm{R}$. Are mouse fetuses which survive microwave radiation permanently affected thereby? Health Phys. 1976;31(1):33-9.

31. Yao KT. Microwave radiation-induced chromosomal aberrations in corneal epithelium of Chinese hamsters. J Hered. 1978;69(6):409-12.

32. Zhang MB, He JL, Jin LF, Lu DQ. Study of low-intensity $2450-\mathrm{MHz}$ microwave exposure enhancing the genotoxic effects of mitomycin C using micronucleus test and comet assay in vitro. Biomed Environ Sci. 2002;15(4): 283-90

33. Zhou XR, Yuan HP, Qu W, Ma CY, Li HY, Wang Y. The study of retinal ganglion cell apoptosis induced by different intensities of microwave irradiation. Ophthalmologica. 2008;222(1):6-10.

34. Naziroglu M, Gumral N. Modulator effects of L-carnitine and selenium on wireless devices (2.45 GHz)-induced oxidative stress and electroencephalography records in brain of rat. Int J Radiat Biol. 2009;85(8): 680-9.

35. Wang LF, Hu XJ, Peng RY, Wang SM, Gao YB, Dong J, et al. Application of ${ }^{1} \mathrm{H}-\mathrm{NMR}$-based metabolomics for detecting injury induced by long-term microwave exposure in Wistar rats' urine. Anal Bioanal Chem. 2012;404:6978.

36. Wang LF, Wei L, Qiao SM, Gao XN, Gao YB, Wang SM, et al. Microwaveinduced structural and functional injury of hippocampal and PC12 cells is accompanied by abnormal changes in the NMDAR-PSD95-CaMKII pathway. Pathobiology. 2015;82:181-94.

37. Qiao SM, Peng RY, Yan HT, Gao YB, Wang CZ, Wang SM, et al. Reduction of phosphorylated synapsin I (Ser-553) leads to spatial memory impairment by attenuating GABA release after microwave exposure in Wistar rats. PLoS One. 2014;9:e95503.

38. Wang LF, Li X, Gao YB, Wang SM, Zhao L, Dong J, et al. Activation of VEGF/ Flk-1-ERK pathway induced blood-brain barrier injury after microwave exposure. Mol Neurobiol. 2015;52:478-91.
39. Zhao L, Li J, Hao YH, Gao YB, Wang SM, Zhang J, et al. Microwave-induced apoptosis and cytotoxicity of NK cells through ERK1/2 signaling. Biomed Environ Sci. 2017;30(5):323-32.

40. Shahin S, Banerjee S, Singh SP, Chaturvedi CM. $2.45 \mathrm{GHz}$ microwave radiation impairs learning and spatial memory via oxidative/nitrosative stress induced p53-dependent/independent hippocampal apoptosis: Molecular basis and underlying mechanism. Toxicol Sci. 2015;148(2):380-99.

41. Shahin S, Singh VP, Shukla RK, Dhawan A, Gangwar RK, Singh SP, et al. 2.45 $\mathrm{GHz}$ microwave irradiation-induced oxidative stress affects implantation or pregnancy in mice, mus musculus. Appl Biochem Biotechnol. 2013;169(5): 1727-51.

42. Kumar S, Kesari KK, Behari J. The therapeutic effect of a pulsed electromagnetic field on the reproductive patterns of male Wistar rats exposed to a 2.45-GHz microwave field. Clinics (Sao Paulo). 2011;66(7):123745.

43. Jin YB, Lee HJ, Lee JS, Pack JK, Kim N, Lee YS. One-year, simultaneous combined exposure of CDMA and WCDMA radiofrequency electromagnetic fields to rats. Int J Radiat Biol. 2011;87(4):416-23.

44. Merritt JH, Kiel JL, Hurt WD. Considerations for human exposure standards for fast-rise-time high-peak-power electromagnetic pulses. Aviat Space Environ Med. 1995;66(6):586-9.

45. Megha K, Deshmukh PS, Banerjee BD, Tripathi AK, Ahmed R, Abegaonkar MP. Low intensity microwave radiation induced oxidative stress, inflammatory response and DNA damage in rat brain. Neurotoxicology. 2015;51:158-65.

46. Razansky D, Kellnberger S, Ntziachristos V. Near-field radiofrequency thermoacoustic tomography with impulse excitation. Med Phys. 2010;37(9): 4602-7.

47. Kazemi F, Mohanna F, Ahmadi-Shokouh J. Microwave reflectometry for noninvasive imaging of skin abnormalities. Australas Phys Eng S. 2018;41(4): 881-90.

48. Islam MT, Samsuzzaman M, Islam MT, Kibria S, Singh MJ. A homogeneous breast phantom measurement system with an improved modified microwave imaging antenna sensor. Sensors (Basel). 2018;18(9):2962.

49. Aldhaeebi MA, Almoneef TS, Ali A, Ren Z, Ramahi OM. Near field breast tumor detection using ultra-narrow band probe with machine learning techniques. Sci Rep. 2018;8(1):12607.

50. Finnie JW, Cai Z, Blumbergs PC, Manavis J, Kuchel TR. Expression of the immediate early gene, c-fos, in fetal brain after whole of gestation exposure of pregnant mice to global system for mobile communication microwaves. Pathology. 2006;38(4):333-5.

51. Finnie JW, Blumbergs PC, Manavis J, Utteridge TD, Gebski V, Davies RA, et al. Effect of long-term mobile communication microwave exposure on vascular permeability in mouse brain. Pathology. 2002;34(4):344-7.

52. Finnie J. Expression of the immediate early gene, c-fos, in mouse brain after acute global system for mobile communication microwave exposure. Pathology. 2005;37(3):231-3.

53. Court-Kowalski S, Finnie JW, Manavis J, Blumbergs PC, Helps SC, Vink R. Effect of long-term (2 years) exposure of mouse brains to global system for mobile communication (GSM) radiofrequency fields on astrocytic immunoreactivity. Bioelectromagnetics. 2015;36(3):245-50.

54. Golomb BA. Diplomats' mystery illness and pulsed radiofrequency/ microwave radiation. Neural Comput. 2018;30(11):2882-5.

55. Belyaev IY, Koch CB, Terenius O, Roxström-Lindquist K, Malmgren LO, H Sommer W, et al. Exposure of rat brain to $915 \mathrm{MHz}$ GSM microwaves induces changes in gene expression but not double stranded DNA breaks or effects on chromatin conformation. Bioelectromagnetics. 2006;27(4):295-306.

56. Belyaev IY, Shcheglov VS, Alipov ED, Ushakov VD. Nonthermal effects of extremely high-frequency microwaves on chromatin conformation in cells in vivo-dependence on physical, physiological, and genetic factors. IEEE T Microw Theory. 2000;48(11):2172-9.

57. Trosic I, Busljeta I, Pavicic I. Blood-forming system in rats after whole-body microwave exposure; reference to the lymphocytes. Toxicol Lett. 2004; 154(1-2):125-32

58. Dasdag S, Ketani MA, Akdag Z, Ersay AR, Sari I, Demirtas OC, et al. Wholebody microwave exposure emitted by cellular phones and testicular function of rats. Urol Res. 1999;27(3):219-23.

59. Tsybulin O, Sidorik E, Brieieva O, Buchynska L, Kyrylenko S, Henshel D, et al. GSM $900 \mathrm{MHz}$ cellular phone radiation can either stimulate or depress early embryogenesis in Japanese quails depending on the duration of exposure. Int J Radiat Biol. 2013;89(9):756-63. 
60. Deichmann WB. Biological effects of microwave radiation of 24,000 megacycles. Arch Toxikol. 1966;22(1):24-35.

61. Michaelson SM. Biomedical aspects of microwave exposure. Am Ind Hyg Assoc J. 1971;32(5):338-45.

62. Berman E, Kinn JB, Ali J, Carter HB, Rehnberg B, Stead AG. Lethality in mice and rats exposed to $2450 \mathrm{MHz}$ circularly polarized microwaves as a function of exposure duration and environmental factors. J Appl Toxicol. 1985;5(1): 23-31.

63. Tofani S, Agnesod G, Ossola P, Ferrini S, Bussi R. Effects of continuous lowlevel exposure to radiofrequency radiation on intrauterine development in rats. Health Phys. 1986;51(4):489-99.

64. Juutilainen J, de Seze R. Biological effects of amplitude-modulated radiofrequency radiation. Scand J Work Environ Health. 1998;24(4):245-54.

65. Zhi WJ, Peng RY, Li HJ, Zou Y, Yao BW, Wang CZ, et al. Microwave radiation leading to shrinkage of dendritic spines in hippocampal neurons mediated by SNK-SPAR pathway. Brain Res. 1679;2018:134-43.

66. Zhao L, Sun CF, Xiong L, Yang YF, Gao YB, Wang LF, et al. MicroRNAs: Novel mechanism involved in the pathogenesis of microwave exposure on rats' hippocampus. J Mol Neurosci. 2014;53(2):222-30.

67. Xiong L, Sun CF, Zhang J, Gao YB, Wang LF, Zuo HY, et al. Microwave exposure impairs synaptic plasticity in the rat hippocampus and PC12 cells through over-activation of the NMDA receptor signaling pathway. Biomed Environ Sci. 2015;28(1):13-24.

68. Wang LF, Tian DW, Li HJ, Gao YB, Wang CZ, Zhao L, et al. Identification of a novel rat NR2b subunit gene promoter region variant and its association with microwave-induced neuron impairment. Mol Neurobiol. 2016;53(4): 2100-11.

69. Wang LF, Peng RY, Hu XJ, Gao YB, Wang SM, Zhao L, et al. Abnormality of synaptic vesicular associated proteins in cerebral cortex and hippocampus after microwave exposure. Synapse. 2009;63(11):1010-6.

70. Vorobyov V, Janać B, Pesić V, Prolić Z. Repeated exposure to low-level extremely low frequency-modulated microwaves affects cortexhypothalamus interplay in freely moving rats: EEG study. Int J Radiat Biol. 2010;86(5):376-83.

71. Saikhedkar N, Bhatnagar M, Jain A, Sukhwal P, Sharma C, Jaiswal N. Effects of mobile phone radiation ( $900 \mathrm{MHz}$ radiofrequency) on structure and functions of rat brain. Neurol Res. 2014;36(12):1072-9.

72. Lin JC, Lin MF. Studies on microwave and blood-brain barrier interaction. Bioelectromagnetics. 1980;1(3):313-23.

73. Li HJ, Peng RY, Wang CZ, Qiao SM, Yong Z, Gao YB, et al. Alterations of cognitive function and 5-HT system in rats after long term microwave exposure. Physiol Behav. 2015;140:236-46.

74. Gökçek-Saraç Ç, Er H, Kencebay Manas C, Kantar Gok D, Özen ફ̧, Derin N. Effects of acute and chronic exposure to both $900 \mathrm{MHz}$ and $2100 \mathrm{MHz}$ electromagnetic radiation on glutamate receptor signaling pathway. Int J Radiat Biol. 2017;93(9):980-9.

75. Bornhausen M, Scheingraber H. Prenatal exposure to $900 \mathrm{MHz}$, cell-phone electromagnetic fields had no effect on operant-behavior performances of adult rats. Bioelectromagnetics. 2000;21(8):566-74.

76. Mausset-Bonnefont AL, Hirbec $H$, Bonnefont $X$, Privat A, Vignon J, de Seze R. Acute exposure to GSM 900-MHz electromagnetic fields induces glial reactivity and biochemical modifications in the rat brain. Neurobiol Dis. 2004;17(3):445-54.

77. Hao YH, Zhang J, Wang H, Wang HY, Dong J, Xu XP, et al. HIF-1 alpha regulates COXIV subunits, a potential mechanism of self-protective response to microwave induced mitochondrial damages in neurons. Sci Rep. 2018; 8(1):10403.

78. Fritze K, Sommer C, Schmitz B, Mies G, Hossmann KA, Kiessling M, et al. Effect of global system for mobile communication (GSM) microwave exposure on blood-brain barrier permeability in rat. Acta Neuropathol. 1997; 94(5):465-70.

79. Zhu WH, Cui Y, Feng XM, Li Y, Zhang W, Xu JJ, et al. The apoptotic effect and the plausible mechanism of microwave radiation on rat myocardial cells. Can J Physiol Pharmacol. 2016;94:849-57.

80. Olgar Y, Hidisoglu E, Celen MC, Yamasan BE, Yargicoglu P, Ozdemir S. 2.1 $\mathrm{GHz}$ electromagnetic field does not change contractility and intracellular $\mathrm{Ca}^{2+}$ transients but decreases $\beta$-adrenergic responsiveness through nitric oxide signaling in rat ventricular myocytes. Int J Radiat Biol. 2015;91:851-7.

81. Liu YQ, Gao YB, Dong J, Yao BW, Zhao L, Peng RY. Pathological changes in the sinoatrial node tissues of rats caused by pulsed microwave exposure. Biomed Environ Sci. 2015;28(1):72-5.
82. Liu YQ, Zhao L, Gao YB, Dong J, Wang H, Yao BW, et al. Dynamic expression of hyperpolarization-activated cyclic nucleotide-gated cation channel 4 involved in microwave induced pacemaker cell injuries. Biomed Environ Sci. 2015;28(11):823-8.

83. Esmekaya MA, Ozer C, Seyhan N. 900 MHz pulse-modulated radiofrequency radiation induces oxidative stress on heart, lung, testis and liver tissues. Gen Physiol Biophys. 2011;30(1):84-9.

84. Kesari KK, Kumar S, Behari J. Mobile phone usage and male infertility in Wistar rats. Indian J Exp Biol. 2010;48(10):987-92.

85. Almasiova V, Holovska K, Simaiova V, Benova K, Racek A, Racekova E, et al. The thermal effect of $2.45 \mathrm{GHz}$ microwave radiation on rat testes. Acta Veterinaria Brno. 2017;86(4):413-9.

86. Nisbet HO, Nisbet C, Akar A, Cevik M, Karayigit MO. Effects of exposure to electromagnetic field $(1.8 / 0.9 \mathrm{GHz})$ on testicular function and structure in growing rats. Res Vet Sci. 2012;93(2):1001-5.

87. Wang BM, Lai H. Acute exposure to pulsed 2450-MHz microwaves affects water-maze performance of rats. Bioelectromagnetics. 2000;21(1):52-6.

88. Türedi S, Hancı H, Çolakoğlu S, Kaya H, Odacı E. Disruption of the ovarian follicle reservoir of prepubertal rats following prenatal exposure to a continuous 900-MHz electromagnetic field. Int J Radiat Biol. 2016;92:329-37.

89. Tsurita G, Nagawa H, Ueno S, Watanabe S, Taki M. Biological and morphological effects on the brain after exposure of rats to a $1439 \mathrm{MHz}$ TDMA field. Bioelectromagnetics. 2000;21(5):364-71.

90. Preston E, Vavasour EJ, Assenheim HM. Permeability of the blood-brain barrier to mannitol in the rat following $2450 \mathrm{MHz}$ microwave irradiation. Brain Res. 1979;174(1):109-17.

91. Merritt JH, Chamness AF, Allen SJ. Studies on blood-brain barrier permeability after microwave-radiation. Radiat Environ Bioph. 1978;15(4): 367-77.

92. Maruyama Y, Nakamura R, Kobayashi K. Effect of microwave irradiation on brain tissue structure and catecholamine distribution. Psychopharmacology. 1980;67(2):119-23.

93. Lai H, Carino MA, Horita A, Guy AW. Single vs. Repeated microwave exposure: Effects on benzodiazepine receptors in the brain of the rat. Bioelectromagnetics. 1992;13(1):57-66.

94. Lai H. Interaction of microwaves and a temporally incoherent magnetic field on spatial learning in the rat. Physiol Behav. 2004;82(5):785-9.

95. Knieriem KM, Medina MA, Stavinoha WB. The levels of GABA in mouse brain following tissue inactivation by microwave irradiation. J Neurochem. 1977; 28(4):885-6.

96. Ammari M, Brillaud E, Gamez C, Lecomte A, Sakly M, Abdelmelek H, et al. Effect of a chronic GSM $900 \mathrm{MHz}$ exposure on glia in the rat brain. Biomed Pharmacother. 2008;62(4):273-81.

97. Alkis ME, Bilgin HM, Akpolat V, Dasdag S, Yegin K, Yavas MC, et al. Effect of 900-, 1800-, and 2100-MHz radiofrequency radiation on DNA and oxidative stress in brain. Electromagn Biol Med. 2019;38(1):32-47.

98. Seaman RL, Phelix CF. Acute effects of pulsed microwaves and 3nitropropionic acid on neuronal ultrastructure in the rat caudate-putarnen. Bioelectromagnetics. 2005;26(2):82-101.

99. Yan JG, Agresti M, Zhang LL, Yan Y, Matloub HS. Upregulation of specific mRNA levels in rat brain after cell phone exposure. Electromagn Biol Med. 2008;27(2):147-54.

100. Yan JG, Agresti M, Zhang LL, Yan Y, Matloub HS. Qualitative effect on mRNAs of injury-associated proteins by cell phone like radiation in rat facial nerves. Electromagn Biol Med. 2009;28(4):383-90.

101. Zhang YW, She F, Li L, Chen CH, Xu SC, Luo X, et al. p25/CDK5 is partially involved in neuronal injury induced by radiofrequency electromagnetic field exposure. Int J Radiat Biol. 2013;89(11):976-84.

102. Xie TR, Pei J, Cui YB, Zhang J, Qi HX, Chen SD, et al. EEG changes as heat stress reactions in rats irradiated by high intensity $35 \mathrm{GHz}$ millimeter waves. Health Phys. 2011;100(6):632-40.

103. Raslear TG, Akyel Y, Bates F, Belt M, Lu ST. Temporal bisection in rats: the effects of high-peak-power pulsed microwave irradiation. Bioelectromagnetics. 1993;14(5):459-78.

104. Türedi S, Hancı H, Topal Z, Ünal D, Mercantepe T, Bozkurt I, et al. The effects of prenatal exposure to a $900-\mathrm{MHz}$ electromagnetic field on the 21-day-old male rat heart. Electromagn Biol Med. 2015;34(4):390-7.

105. Smith TL, Wong-Gibbons D, Maultsby J. Microcirculatory effects of pulsed electromagnetic fields. J Orthop Res. 2004;22(1):80-4.

106. Li BF, Guo GZ, Ren DQ, Jing L, Zhang RB. Electromagnetic pulses induce fluctuations in blood pressure in rats. Int J Radiat Biol. 2007:83(6):421-9. 
107. Kerimoğlu G, Mercantepe T, Erol HS, Turgut A, Kaya H, Çolakoğlu S, et al. Effects of long-term exposure to 900 megahertz electromagnetic field on heart morphology and biochemistry of male adolescent rats. Biotech Histochem. 2016;91(7):445-54.

108. Kalns J, Ryan KL, Mason PA, Bruno JG, Gooden R, Kiel JL. Oxidative stress precedes circulatory failure induced by $35-\mathrm{GHz}$ microwave heating. Shock. 2000;13(1):52-9

109. Millenbaugh NJ, Roth C, Sypniewska R, Chan V, Eggers JS, Kiel JL, et al. Gene expression changes in the skin of rats induced by prolonged $35 \mathrm{GHz}$ millimeter-wave exposure. Radiat Res. 2008;169(3):288-300.

110. Deshmukh PS, Megha K, Nasare N, Banerjee BD, Ahmed RS, Abegaonkar MP, et al. Effect of low level subchronic microwave radiation on rat brain. Biomed Environ Sci. 2016;29(12):858-67.

111. Deshmukh PS, Nasare N, Megha K, Banerjee BD, Ahmed RS, Singh D, et al. Cognitive impairment and neurogenotoxic effects in rats exposed to lowintensity microwave radiation. Int J Toxicol. 2015;34(3):284-90.

112. Deshmukh PS, Banerjee BD, Abegaonkar MP, Megha K, Ahmed RS, Tripath AK, et al. Effect of low level microwave radiation exposure on cognitive function and oxidative stress in rats. Indian J Biochem Biophys. 2013;50(2): 114-9.

113. Megha K, Deshmukh PS, Banerjee BD, Tripathi AK, Abegaonkar MP. Microwave radiation induced oxidative stress, cognitive impairment and inflammation in brain of Fischer rats. Indian J Exp Biol. 2012;50(12):889-96.

114. Eberhardt JL, Persson BR, Brun AE, Salford LG, Malmgren LO. Blood-brain barrier permeability and nerve cell damage in rat brain 14 and 28 days after exposure to microwaves from GSM mobile phones. Electromagn Biol Med. 2008;27(3):215-29.

115. Salford LG, Brun A, Sturesson K, Eberhardt JL, Persson BR. Permeability of the blood-brain barrier induced by $915 \mathrm{MHz}$ electromagnetic radiation, continuous wave and modulated at 8, 16, 50, and $200 \mathrm{~Hz}$. Microsc Res Tech. 1994;27(6):535-42.

116. de Gannes FP, Billaudel B, Taxile M, Haro E, Ruffié G, Lévêque $P$, et al. Effects of head-only exposure of rats to GSM-900 on blood-brain barrier permeability and neuronal degeneration. Radiat Res. 2009;172(3):359-67.

117. Kuribayashi M, Wang JQ, Fujiwara O, Doi Y, Nabae K, Tamano S, et al. Lack of effects of $1439 \mathrm{MHz}$ electromagnetic near field exposure on the bloodbrain barrier in immature and young rats. Bioelectromagnetics. 2005;26(7): 578-88.

118. McQuade JM, Merritt JH, Miller SA, Scholin T, Cook MC, Salazar A, et al. Radiofrequency-radiation exposure does not induce detectable leakage of albumin across the blood-brain barrier. Radiat Res. 2009;171(5):615-21.

119. Xu Q, Tong J, Jin ZD, Lu MX, Du HB, Cao Y. Radiation protection and possible mechanisms for low intensity microwave. Chin J Ind Hyg Occup Dis. 2009;27(9):520-4. (Article in China).

120. Xu FL, Bai QD, Zhou K, Ma L, Duan JJ, Zhuang FL, et al. Age-dependent acute interference with stem and progenitor cell proliferation in the hippocampus after exposure to $1800 \mathrm{MHz}$ electromagnetic radiation. Electromagn Biol Med. 2017;36(2):158-66.

121. Sharma A, Kesari KK, Saxena VK, Sisodia R. The influence of prenatal $10 \mathrm{GHz}$ microwave radiation exposure on a developing mice brain. Gen Physiol Biophys. 2017;36(1):41-51.

122. Shahin S, Mishra V, Singh SP, Chaturvedi CM. 2.45-GHz microwave irradiation adversely affects reproductive function in male mouse, Mus. musculus by inducing oxidative and nitrosative stress. Free Radic Res. 2014; 48:511-25.

123. Jones DJ, Stavinoha WB. Levels of cyclic nucleotides in mouse regional brain following 300 ms microwave inactivation. J Neurochem. 1977;28(4): 759-63.

124. Van Eeghem V, El Arfani A, Anthoula A, Walrave L, Pourkazemi A, Bentea E, et al. Selective changes in locomotor activity in mice due to low-intensity microwaves amplitude modulated in the EEG spectral domain. Neuroscience. 2017:359:40-8.

125. Kim JH, Lee $\mathrm{CH}$, Kim HG, Kim HR. Decreased dopamine in striatum and difficult locomotor recovery from MPTP insult after exposure to radiofrequency electromagnetic fields. Sci Rep. 2019;9(1):1201.

126. Kim TH, Huang TQ, Jang JJ, Kim MH, Kim HJ, Lee JS, et al. Local exposure of 849 $\mathrm{MHz}$ and $1763 \mathrm{MHz}$ radiofrequency radiation to mouse heads does not induce cell death or cell proliferation in brain. Exp Mol Med. 2008;40(3):294-303.

127. Saran A, Pazzaglia S, Mancuso M, Rebessi S, Di Majo V, Tanori M, et al. Marino C. Effects of exposure of newborn patched 1 heterozygous mice to GSM, 900 MHz. Radiat Res. 2007;168(6):733-40.
128. Utteridge T, Gebski V, Finnie J, Vernon-Roberts B, Kuchel T. Long-term exposure of E-mu-Pim1 transgenic mice to $898.4 \mathrm{MHz}$ microwaves does not increase lymphoma incidence. Radiat Res. 2002;158(3):357-64.

129. Guler G, Tomruk A, Ozgur E, Seyhan N. The effect of radiofrequency radiation on DNA and lipid damage in non-pregnant and pregnant rabbits and their newborns. Gen Physiol Biophys. 2010;29(1):59-66.

130. Tomruk A, Guler G, Dincel AS. The influence of $1800 \mathrm{MHz}$ GSM-like signals on hepatic oxidative DNA and lipid damage in nonpregnant, pregnant, and newly born rabbits. Cell Biochem Biophys. 2010;56(1):39-47.

131. Kismali G, Ozgur E, Guler G, Akcay A, Sel T, Seyhan N. The influence of 1800 $\mathrm{MHz}$ GSM-like signals on blood chemistry and oxidative stress in nonpregnant and pregnant rabbits. Int J Radiat Biol. 2012;88(5):414-9.

132. Salama N, Kishimoto T, Kanayama HO. Effects of exposure to a mobile phone on testicular function and structure in adult rabbit. Int J Androl. 2010;33(1):88-94.

133. Güler G, Ozgur E, Keles H, Tomruk A, Vural SA, Seyhan N. Neurodegenerative changes and apoptosis induced by intrauterine and extrauterine exposure of radiofrequency radiation. J Chem Neuroanat. 2016;75(Pt B):128-33.

134. Salama N, Kishimoto T, Kanayama HO, Kagawa S. Effects of exposure to a mobile phone on sexual behavior in adult male rabbit: An observational study. Int J Impot Res. 2010;22(2):127-33.

135. Carpenter RL, Biddle DK, Van Ummersen CA. Opacities in the lens of the eye experimentally induced by exposure to microwave radiation. IRE Trans Med Electron. 1960;ME-7:152-7.

136. Oldendorf WH. Focal neurological lesions produced by microwave irradiation. Proc Soc Exp Biol Med. 1949;72(2):432-4.

137. Paulsson LE, Hamnerius Y, Hansson HA, Sjostrand J. Retinal damage experimentally induced by microwave radiation at $55 \mathrm{~mW} / \mathrm{cm}^{2}$. Acta Ophthalmol. 1979;57(2):183-97.

138. Sutton $\mathrm{CH}$. Graded spinal cord injuries produced in rabbits with noninvasive microwave hyperthermia. J Am Paraplegia Soc. 1988;11(2):41-9.

139. Wood MA, Fuller IA. Acute and chronic electrophysiologic changes surrounding radiofrequency lesions. J Cardiovasc Electrophysiol. 2002;13(1): 56-61.

140. Lu ST, D'Andrea J, Chalfin S, Crane C, Marchello D, Garay R, et al. Absence of corneal endothelium injury in non-human primates treated with and without ophthalmologic drugs and exposed to $2.8 \mathrm{GHz}$ pulsed microwaves. Bioelectromagnetics. 2010;31(4):324-33.

141. Chalfin S, D'Andrea JA, Comeau PD, Belt ME, Hatcher DJ. Millimeter wave absorption in the nonhuman primate eye at $35 \mathrm{GHz}$ and $94 \mathrm{GHz}$. Health Phys. 2002;83(1):83-90.

142. Lu ST, Mathur SP, Stuck B, Zwick H, D'Andrea JA, Ziriax JM, et al. Effects of high peak power microwaves on the retina of the rhesus monkey. Bioelectromagnetics. 2000;21(6):439-54.

143. Kues HA, D'Anna SA, Osiander R, Green WR, Monahan JC. Absence of ocular effects after either single or repeated exposure to $10 \mathrm{~mW} / \mathrm{cm}^{2}$ from a 60 GHz CW source. Bioelectromagnetics. 1999;20(8):463-73.

144. Foster KR, D'Andrea JA, Chalfin S, Hatcher DJ. Thermal modeling of millimeter wave damage to the primate cornea at $35 \mathrm{GHz}$ and $94 \mathrm{GHz}$. Health Phys. 2003;84(6):764-9.

145. Pawlak K, Sechman A, Nieckarz Z. Plasma thyroid hormones and corticosterone levels in blood of chicken embryos and post hatch chickens exposed during incubation to $1800 \mathrm{MHz}$ electromagnetic field. Int J Occup Med Environ Health. 2014;27(1):114-22.

146. Daniells C, Duce I, Thomas D, Sewell P, Tattersall J, de Pomerai D. Transgenic nematodes as biomonitors of microwave-induced stress. Mutat Res-fund Mol M. 1998;399(1):55-64.

147. Wang H, Zhang J, Hu SH, Tan SZ, Zhang B, Zhou HM, et al. Real-time microwave exposure induces calcium efflux in primary hippocampal neurons and primary cardiomyocytes. Biomed Environ Sci. 2018;31(8):56171.

148. Schirmacher A, Winters S, Fischer S, Goeke J, Galla HJ, Kullnick U, et al. Electromagnetic fields $(1.8 \mathrm{GHz})$ increase the permeability to sucrose of the blood-brain barrier in vitro. Bioelectromagnetics. 2000;21(5):338-45.

149. Su L, Yimaer A, Xu Z, Chen G. Effects of $1800 \mathrm{MHz}$ RF-EMF exposure on DNA damage and cellular functions in primary cultured neurogenic cells. Int J Radiat Biol. 2018;94(3):295-305.

150. Platano D, Mesirca P, Paffi A, Pellegrino M, Liberti M, Apollonio F, et al. Acute exposure to low-level CW and GSM-modulated $900 \mathrm{MHz}$ radiofrequency does not affect $\mathrm{Ba}^{2+}$ currents through voltage-gated calcium channels in rat cortical neurons. Bioelectromagnetics. 2007;28(8):599-607. 
151. Zhao L, Yang YF, Gao YB, Wang SM, Wang LF, Zuo HY, et al. Upregulation of HIF-1 alpha via activation of ERK and PI3K pathway mediated protective response to microwave-induced mitochondrial injury in neuron-like cells. Mol Neurobiol. 2014;50(3):1024-34.

152. Park J, Kwon JH, Kim N, Song K. Effects of 1950 MHz radiofrequency electromagnetic fields on $A \beta$ processing in human neuroblastoma and mouse hippocampal neuronal cells. J Radiat Res. 2018;59(1):18-26.

153. Li X, Xu HX, Lei T, Yang YF, Jing D, Dai SH, et al. A pulsed electromagnetic field protects against glutamate-induced excitotoxicity by modulating the endocannabinoid system in HT22 cells. Front Neurosci. 2017;11:42.

154. Lekhraj R, Cynamon DE, DeLuca SE, Taub ES, Pilla AA, Casper D. Pulsed electromagnetic fields potentiate neurite outgrowth in the dopaminergic MN9D cell line. J Neurosci Res. 2014;92(6):761-71.

155. Xue L, Wang SM, Chen HY, Peng RY, Zuo HY, Wang LF, et al. Microwave radiation induces injury to GC-2spd cells. Natl J Androl. 2014;20(3):201-6. (Article in China).

156. Liu C, Duan W, Xu S, Chen C, He M, Zhang L, et al. Exposure to $1800 \mathrm{MHz}$ radiofrequency electromagnetic radiation induces oxidative DNA base damage in a mouse spermatocyte-derived cell line. Toxicol Lett. 2013;218(1): 2-9.

157. Hofmann MC, Hess RA, Goldberg E, Millán JL. Immortalized germ cells undergo meiosis in vitro. Proc Natl Acad Sci USA. 1994;91(12):5533-7.

158. Mikuz G. The multitasking sertoli cell. Der Pathologe. 2019;40(Suppl 3):31824.

159. Deng H, Wang DW, Peng RY, Wang SM, Chen JK, Zhang S, et al. The electroporation effects of high power pulse microwave and electromagnetic pulse irradiation on the membranes of cardiomyocyte cells and the mechanism therein involved. J Biomedical Eng. 2005;22(4):672-6. (Article in China).

160. Wolke S, Neibig U, Elsner R, Gollnick F, Meyer R. Calcium homeostasis of isolated heart muscle cells exposed to pulsed high-frequency electromagnetic fields. Bioelectromagnetics. 1996;17(2):144-53.

161. Surducan V, Surducan E, Neamtu C, Mot A, Ciorîță A. Effects of long-term exposure to low-power $915 \mathrm{MHz}$ unmodulated radiation on phaseolus vulgaris L. Bioelectromagnetics. 2020;41(3):200-12.

162. Kumar A, Kaur S, Chandel S, Singh HP, Batish DR, Kohli RK. Comparative cyto- and genotoxicity of $900 \mathrm{MHz}$ and $1800 \mathrm{MHz}$ electromagnetic field radiations in root meristems of Allium cepa. Ecotox Environ Safe. 2020;188: 109786

163. Movahedi MM, Nouri F, Tavakoli Golpaygani A, Ataee L, Amani S, Taheri M. Pseudomonas aeruginosa antibacterial susceptibility pattern of the and after exposure to electromagnetic waves emitted from mobile phone simulator. J Biomed Phys Eng. 2019;9(6):637-46.

164. Yang SC, Lin HC, Liu TM, Lu JT, Hung WT, Huang YR, et al. Efficient structure resonance energy transfer from microwaves to confined acoustic vibrations in viruses. Sci Rep. 2015;5:18030

165. Sun CK, Tsai YC, Chen YE, Liu TM, Chen HY, Wang HC, et al. Resonant dipolar coupling of microwaves with confined acoustic vibrations in a rodshaped virus. Sci Rep. 2017;7(1):4611.

166. Burgess AP, Fouquet NC, Seri S, Hawken MB, Heard A, Neasham D, et al. Acute exposure to terrestrial trunked radio (TETRA) has effects on the electroencephalogram and electrocardiogram, consistent with vagal nerve stimulation. Environ Res. 2016:150:461-9.

167. Vorhees CV, Williams MT. Morris water maze: Procedures for assessing spatial and related forms of learning and memory. Nat Protoc. 2006;1(2): $848-58$

168. Zhang YC, Li ZH, Gao Y, Zhang CG. Effects of fetal microwave radiation exposure on offspring behavior in mice. J Radiat Res. 2015;56(2):261-8.

169. Narayanan SN, Kumar RS, Potu BK, Nayak S, Mailankot M. Spatial memory performance of Wistar rats exposed to mobile phone. Clinics (Sao Paulo). 2009;64(3):231-4.

170. Tian Y, Xia ZM, Li M, Zhang GJ, Cui HM, Li B, et al. The relationship between microwave radiation injury and abnormal lipid metabolism. Chem Phys Lipids. 2019;225:104802.

171. Sienkiewicz ZJ, Blackwell RP, Haylock RGE, Saunders RD, Cobb BL. Low-level exposure to pulsed $900 \mathrm{MHz}$ microwave radiation does not cause deficits in the performance of a spatial learning task in mice. Bioelectromagnetics. 2000;21(3):151-8.

172. Sinha RK. Chronic non-thermal exposure of modulated $2450 \mathrm{MHz}$ microwave radiation alters thyroid hormones and behavior of male rats. Int J Radiat Biol. 2008;84(6):505-13.
173. Walf AA, Frye CA. The use of the elevated plus maze as an assay of anxietyrelated behavior in rodents. Nat Protoc. 2007:2(2):322-8.

174. Prut $L$, Belzung C. The open field as a paradigm to measure the effects of drugs on anxiety-like behaviors: A review. Eur J Pharmacol. 2003;463(1-3):333

175. Vorobyov W, Galchenko AA, Kukushkin NI, Akoev IG. Effects of weak microwave fields amplitude modulated at ELF on EEG of symmetric brain areas in rats. Bioelectromagnetics. 1997;18(4):293-8.

176. Takashima S, Onaral B, Schwan HP. Effects of modulated RF energy on the EEG of mammalian brains. Effects of acute and chronic irradiations. Radiat Environ Bioph. 1979;16(1):15-27.

177. Suhhova A, Bachmann M, Karai D, Lass J, Hinrikus H. Effect of microwave radiation on human EEG at two different levels of exposure. Bioelectromagnetics. 2013;34(4):264-74.

178. Schmid MR, Murbach M, Lustenberger C, Maire M, Kuster N, Achermann P, et al. Sleep EEG alterations: Effects of pulsed magnetic fields versus pulsemodulated radio frequency electromagnetic fields. J Sleep Res. 2012;21(6): 620-9.

179. Schmid MR, Loughran SP, Regel SJ, Murbach M, Bratic Grunauer A, Rusterholz T, et al. Sleep EEG alterations: effects of different pulsemodulated radio frequency electromagnetic fields. J Sleep Res. 2012;21(1): 50-8.

180. Nakatani-Enomoto S, Yamazaki M, Nishiura K, Enomoto H, Ugawa Y. Effects of electromagnetic fields from long-term evolution on awake electroencephalogram in healthy humans. Neurosci Res. 2020;156:102-7.

181. Regel SJ, Tinguely G, Schuderer J, Adam M, Kuster N, Landolt HP, et al. Pulsed radio-frequency electromagnetic fields: dose-dependent effects on sleep, the sleep EEG and cognitive performance. J Sleep Res. 2007;16(3): 253-8.

182. Lustenberger C, Murbach M, Tüshaus L, Wehrle F, Kuster N, Achermann $P$, et al Inter-individual and intra-individual variation of the effects of pulsed RF EMF exposure on the human sleep EEG. Bioelectromagnetics. 2015;36(3):169-77.

183. Huber R, Treyer V, Schuderer J, Berthold T, Buck A, Kuster N, et al. Exposure to pulse-modulated radio frequency electromagnetic fields affects regional cerebral blood flow. Eur J Neurosci. 2005;21(4):1000-6.

184. Huber R, Treyer V, Borbély AA, Schuderer J, Gottselig JM, Landolt HP, et al. Electromagnetic fields, such as those from mobile phones, alter regional cerebral blood flow and sleep and waking EEG. J Sleep Res. 2002;11(4):289-95.

185. Huber R, Graf T, Cote KA, Wittmann L, Gallmann E, Matter D, et al. Exposure to pulsed high-frequency electromagnetic field during waking affects human sleep EEG. Neuroreport. 2000;11(15):3321-5.

186. Hietanen M, Kovala T, Hämäläinen AM. Human brain activity during exposure to radiofrequency fields emitted by cellular phones. Scand J Work Environ Health. 2000;26(2):87-92.

187. Yao L, Xue X, Yu P, Ni Y, Chen F. Evans blue dye: A revisit of its applications in biomedicine. Contrast Media Mol I. 2018;2018:7628037.

188. Sirav B, Seyhan N. Effects of GSM modulated radio-frequency electromagnetic radiation on permeability of blood-brain barrier in male \& female rats. J Chem Neuroanat. 2016:75(Pt B):123-7.

189. Tang J, Zhang Y, Yang LM, Chen QW, Tan L, Zuo SL, et al. Exposure to 900 $\mathrm{MHz}$ electromagnetic fields activates the mkp-1/ERK pathway and causes blood-brain barrier damage and cognitive impairment in rats. Brain Res. 1601:2015:92-101.

190. Finnie JW, Blumbergs PC, Manavis J, Utteridge TD, Gebski V, Swift JG, et al Effect of global system for mobile communication (GSM)-like radiofrequency fields on vascular permeability in mouse brain. Pathology. 2001;33(3):338-40

191. Shahin NN, El-Nabarawy NA, Gouda AS, Mégarbane B. The protective role of spermine against male reproductive aberrations induced by exposure to electromagnetic field - An experimental investigation in the rat. Toxicol Appl Pharmacol. 2019;370:117-30.

192. Dasdag S, Taş M, Akdag MZ, Yegin K. Effect of long-term exposure of 2.4 $\mathrm{GHz}$ radiofrequency radiation emitted from Wi-Fi equipment on testes functions. Electromagn Biol Med. 2015:34:37-42.

193. Wang ZP, Fei $Y$, Liu H, Zheng SS, Ding ZY, Jin W, et al. Effects of electromagnetic fields exposure on plasma hormonal and inflammatory pathway biomarkers in male workers of a power plant. Int Arch Occup Environ Health. 2016:89:33-42.

194. Forgács Z, Somosy Z, Kubinyi G, Bakos J, Hudák A, Surján A, et al. Effect of whole-body $1800 \mathrm{MHz}$ GSM-like microwave exposure on testicular steroidogenesis and histology in mice. Reprod Toxicol. 2006;22(1):111-7. 
195. Jin YB, Choi HD, Kim BC, Pack JK, Kim N, Lee YS. Effects of simultaneous combined exposure to CDMA and WCDMA electromagnetic fields on serum hormone levels in rats. J Radiat Res. 2013;54(3):430-7.

196. Trošić I, Mataušić-Pišl M, Pavičić I, Marjanović AM. Histological and cytological examination of rat reproductive tissue after short-time intermittent radiofrequency exposure. Arh Hig Rada Toksiko. 2013;64(4):513-9.

197. Huber R, Schuderer J, Graf T, Jütz K, Borbély AA, Kuster N, et al. Radio frequency electromagnetic field exposure in humans: Estimation of SAR distribution in the brain, effects on sleep and heart rate. Bioelectromagnetics. 2003;24(4):262-76.

198. Choi SB, Kwon MK, Chung JW, Park JS, Chung K, Kim DW. Effects of shortterm radiation emitted by wcdma mobile phones on teenagers and adults. BMC Public Health. 2014;14:438.

199. Szyjkowska A, Gadzicka E, Szymczak W, Bortkiewicz A. The reaction of the circulatory system to stress and electromagnetic fields emitted by mobile phones - 24-h monitoring of ECG and blood pressure. Med Pr. 2019;70(4):411-24.

200. Nam KC, Kim SW, Kim SC, Kim DW. Effects of RF exposure of teenagers and adults by CDMA cellular phones. Bioelectromagnetics. 2006;27(7):509-14.

201. Lu ST, Mathur SP, Akyel Y, Lee JC. Ultrawide-band electromagnetic pulses induced hypotension in rats. Physiol Behav. 1999;65(4-5):753-61.

202. Braune S, Riedel A, Schulte-Mönting J, Raczek J. Influence of a radiofrequency electromagnetic field on cardiovascular and hormonal parameters of the autonomic nervous system in healthy individuals. Radiat Res. 2002;158(3):352-6.

203. Singh S, Mani KV, Kapoor N. Effect of occupational EMF exposure from radar at two different frequency bands on plasma melatonin and serotonin levels. Int J Radiat Biol. 2015;91(5):426-34.

204. Mahdavi SM, Sahraei H, Yaghmaei P, Tavakoli $H$. Effects of electromagnetic radiation exposure on stress-related behaviors and stress hormones in male Wistar rats. Biomol Ther (Seoul). 2014;22(6):570-6

205. Kalanjati VP, Purwantari KE, Prasetiowati L. Aluminium foil dampened the adverse effect of $2100 \mathrm{MHz}$ mobile phone-induced radiation on the blood parameters and myocardium in rats. Environ Sci Pollut Res Int. 2019;26(12): 11686-9.

206. Zhu W, Shen N, Zhong X, Hou J, Lü S, Cai J. The cardiac injury effect of microwave radiation on rabbit and its mechanism. J Hyg Res. 2015;44(5): 818-21

207. Keleş Al, Nyengaard JR, Odacı E. Changes in pyramidal and granular neuron numbers in the rat hippocampus 7 days after exposure to a continuous 900-MHz electromagnetic field during early and mid-adolescence. J Chem Neuroanat. 2019;101:101681.

208. Almášiová V, Holovská K, Cigánková V, Račeková E, Fabianová K, Martončíková M. Structural and ultrastructural study of rat testes influenced by electromagnetic radiation. J Toxicol Environ Health Part A. 2014;77(13): $747-50$

209. Hancı H, Kerimoğlu G, Mercantepe T, Odacı E. Changes in testicular morphology and oxidative stress biomarkers in 60-day-old Sprague Dawley rats following exposure to continuous 900-MHz electromagnetic field for 1 h a day throughout adolescence. Reprod Toxicol. 2018:81:71-8.

210. Paulraj R, Behari J. Enzymatic alterations in developing rat brain cells exposed to a low-intensity $16.5 \mathrm{GHz}$ microwave radiation. Electromagn Biol Med. 2012;31(3):233-42.

211. Kumar S, Kesari KK, Behari J. Influence of microwave exposure on fertility of male rats. Fertil Steril. 2011;95(4):1500-2.

212. Kesari KK, Behari J. Microwave exposure affecting reproductive system in male rats. Appl Biochem Biotech. 2010;162(2):416-28.

213. Odacı E, Özyılmaz C. Exposure to a $900 \mathrm{MHz}$ electromagnetic field for 1 hour a day over 30 days does change the histopathology and biochemistry of the rat testis. Int J Radiat Biol. 2015;91(7):547-54.

214. Zhu Y, Gao F, Yang X, Shen $H$, Liu W, Chen $H$, Jiang X. The effect of microwave emission from mobile phones on neuron survival in rat central nervous system. Prog Electromagn Res. 2008;82:287-98.

215. Dasdag S, Akdag MZ, Ulukaya E, Uzunlar AK, Yegin D. Mobile phone exposure does not induce apoptosis on spermatogenesis in rats. Arch Med Res. 2008:39(1):40-4

216. Dasdag S, Akdag MZ, Ulukaya E, Uzunlar AK, Ocak AR. Effect of mobile phone exposure on apoptotic glial cells and status of oxidative stress in rat brain. Electromagn Biol Med. 2009;28(4):342-54.

217. Jeong S, Park MJ, Song W, Kim HS. Current immunoassay methods and their applications to clinically used biomarkers of breast cancer. Clin Biochem. 2020;78:43-57.
218. Bilgici B, Gun S, Avci B, Akar A. K Engiz B. What is adverse effect of wireless local area network, using $2.45 \mathrm{GHz}$, on the reproductive system? Int J Radiat Biol. 2018;94(11):1054-61

219. Zhadobov M, Sauleau R, Le Coq L, Debure L, Thouroude D, Michel D, et al. Low-power millimeter wave radiations do not alter stress-sensitive gene expression of chaperone proteins. Bioelectromagnetics. 2007;28(3):188-96.

220. Jorge-Mora T, Misa-Agustiño MJ, Rodríguez-González JA, Jorge-Barreiro FJ, Ares-Pena FJ, López-Martín E. The effects of single and repeated exposure to $2.45 \mathrm{GHz}$ radiofrequency fields on c-Fos protein expression in the paraventricular nucleus of rat hypothalamus. Neurochem Res. 2011;36(12): 2322-32.

221. Kellner R. Proteomics. Concepts and perspectives. Fresenius J Anal Chem. 2000;366(6-7):517-24.

222. Sepehrimanesh M, Kazemipour N, Saeb M, Nazifi S, Davis DL. Proteomic analysis of continuous $900-\mathrm{MHz}$ radiofrequency electromagnetic field exposure in testicular tissue: A rat model of human cell phone exposure. Environ Sci Pollut Res Int. 2017:24(15):13666-73.

223. Wu H, Wang D, Meng $Y$, Ning H, Liu X, Xie $Y$, et al. Activation of TLR signalling regulates microwave radiation-mediated impairment of spermatogenesis in rat testis. Andrologia. 2018;50(1). doi: 10.1111/and.12828.

224. Kumar R, Deshmukh PS, Sharma S, Banerjee B. Activation of endoplasmic reticulum stress in rat brain following low-intensity microwave exposure. Environ Sci Pollut Res Int. 2019;26(9):9314-21.

225. Fritze K, Wiessner C, Kuster N, Sommer C, Gass P, Hermann DM, et al. Effect of global system for mobile communication microwave exposure on the genomic response of the rat brain. Neuroscience. 1997;81(3):627-39.

226. Yao K, Wu W, Yu Y, Zeng Q, He J, Lu D, Wang K. Effect of superposed electromagnetic noise on DNA damage of lens epithelial cells induced by microwave radiation. Invest Ophthalmol Vis Sci. 2008;49(5):2009-15.

227. Kesari KK, Meena R, Nirala J, Kumar J, Verma HN. Effect of $3 \mathrm{G}$ cell phone exposure with computer controlled 2-D stepper motor on non-thermal activation of the hsp27/p38MAPK stress pathway in rat brain. Cell Biochem Biophys. 2014;68(2):347-58.

228. Maruyama Y, Kusaka M. Assay of norepinephrine and dopamine in the rat brain after microwave irradiation. Life Sci. 1978;23(15):1603-8.

229. Reinhold AK, Rittner HL. Barrier function in the peripheral and central nervous system-A review. Pflugers Arch. 2017;469(1):123-34.

230. Li D, Liu X, Liu T, Liu H, Tong L, Jia S, et al. Neurochemical regulation of the expression and function of glial fibrillary acidic protein in astrocytes. Glia. 2020;68(5):878-97.

231. Lagos-Cabré R, Burgos-Bravo F, Avalos AM, Leyton L. Connexins in astrocyte migration. Front Pharmacol. 2019;10:1546.

232. Malek F, Rani KA, Rahim HA, Omar MH. Effect of short-term mobile phone base station exposure on cognitive performance, body temperature, heart rate and blood pressure of malaysians. Sci Rep. 2015;5:13206

233. Umar ZU, Abubakar MB, Ige J, Igbokwe UV, Mojiminiyi FBO, Isezuo SA. Effect of mobile phone radiofrequency electromagnetic fields on. Niger J Physiol Sci. 2014;29(2):137-40.

234. Béres S, Németh Á, Ajtay Z, Kiss I, Németh B, Hejjel L. Cellular phone irradiation of the head affects heart rate variability depending on inspiration/expiration ratio. In Vivo. 2018:32(5):1145-53.

235. Andrzejak R, Poreba R, Poreba M, Derkacz A, Skalik R, Gac P, et al. The influence of the call with a mobile phone on heart rate variability parameters in healthy volunteers. Ind Health. 2008;46(4):409-17.

236. Barutcu I, Esen AM, Kaya D, Turkmen M, Karakaya O, Saglam M, et al. Do mobile phones pose a potential risk to autonomic modulation of the heart? Pacing Clin Electrophysiol. 2011;34(11):1511-4.

237. Parazzini M, Ravazzani P, Thuroczy G, Molnar FB, Ardesi G, Sacchettini A, et al. Nonlinear heart rate variability measures under electromagnetic fields produced by GSM cellular phones. Electromagn Biol Med. 2013;32(2):17381.

238. Misek J, Belyaev I, Jakusova V, Tonhajzerova I, Barabas J, Jakus J. Heart rate variability affected by radiofrequency electromagnetic field in adolescent students. Bioelectromagnetics. 2018;39(4):277-88.

239. Sun W, Yang YD, Yu HM, Wang LW, Pan S. The synergistic effect of microwave radiation and hypergravity on rats and the intervention effect of Rana sylvatica Le conte oil. Dose Response. 2017;15(2):1559325817711511.

240. Djeridane Y, Touitou Y, De Seze R. Influence of electromagnetic fields emitted by GSM-900 cellular telephones on the circadian patterns of gonadal, adrenal and pituitary hormones in men. Radiat Res. 2008;169(3): 337-43. 
241. Testylier G, Tonduli L, Malabiau R, Debouzy JC. Effects of exposure to low level radiofrequency fields on acetylcholine release in hippocampus of freely moving rats. Bioelectromagnetics. 2002;23(4):249-55.

242. Ammari M, Lecomte A, Sakly M, Abdelmelek H. de-Seze R. Exposure to GSM $900 \mathrm{MHz}$ electromagnetic fields affects cerebral cytochrome c oxidase activity. Toxicology. 2008;250(1):70-4.

243. Sanders AP, Schaefer DJ, Joines WT. Microwave effects on energy metabolism of rat brain. Bioelectromagnetics. 1980;1(2):171-81.

244. Hao YH, Zhao L, Peng RY. Effects of microwave radiation on brain energy metabolism and related mechanisms. Mil Med Res. 2015;2:4-4.

245. Kesari KK, Kumar S, Behari J. 900-MHz microwave radiation promotes oxidation in rat brain. Electromagn Biol Med. 2011;30(4):219-34.

246. Marjanovic Cermak AM, Pavicic I, Tariba Lovakovic B, Pizent A, Trosic I. In vitro non-thermal oxidative stress response after $1800 \mathrm{MHz}$ radiofrequency radiation. Gen Physiol Biophys. 2017:36(4):407-14.

247. Kuybulu AE, Oktem F, Ciris IM, Sutcu R, Ormeci AR, Comlekci S, et al. Effects of long-term pre- and post-natal exposure to $2.45 \mathrm{GHz}$ wireless devices on developing male rat kidney. Renal Failure. 2016;38(4):571-80.

248. Shallom JM, Di Carlo AL, Ko DJ, Penafiel LM, Nakai A, Litovitz TA. Microwave exposure induces hsp70 and confers protection against hypoxia in chick embryos. J Cell Biochem. 2002;86(3):490-6.

249. Li YZ, Qu XL, Wang XR, Liu M, Wang C, Lv ZR, et al. Microwave radiation injures microvasculature through inducing endoplasmic reticulum stress. Microcirculation. 2014;21(6):490-8.

250. Kim JH, Yu DH, Huh YH, Lee EH, Kim HG, Kim HR. Long-term exposure to $835 \mathrm{MHz}$ RF-EMF induces hyperactivity, autophagy and demyelination in the cortical neurons of mice. Sci Rep. 2017;7:41129.

251. Liu K, Zhang G, Wang Z, Liu Y, Dong J, Dong X, et al. The protective effect of autophagy on mouse spermatocyte derived cells exposure to $1800 \mathrm{MHz}$ radiofrequency electromagnetic radiation. Toxicol Lett. 2014;228(3):216-24.

252. Kesari KK, Behari J, Kumar S. Mutagenic response of $2.45 \mathrm{GHz}$ radiation exposure on rat brain. Int J Radiat Biol. 2010;86(4):334-43.

253. Pall ML. Electromagnetic fields act via activation of voltage-gated calcium channels to produce beneficial or adverse effects. J Cell Mol Med. 2013; 17(8):958-65.

254. Zhang J, Peng RY, Gao YB, Wang SM, Yang LL, Zhao L, et al. Aduola Fuzhenglin down-regulates microwave-induced expression of $\beta_{1}$-adrenergic receptor and muscarinic type 2 acetylcholine receptor in myocardial cells of rats. Biomed Environ Sci. 2014;27(3):204-7.

255. Kesari KK, Behari J. Fifty-gigahertz microwave exposure effect of radiations on rat brain. Appl Biochem Biotechnol. 2009;158(1):126-39.

256. Karaca E, Durmaz B, Aktug H, Altug H, Yildiz T, Guducu C, et al. The genotoxic effect of radiofrequency waves on mouse brain. J Neurooncol. 2012;106(1):53-8.

257. Furtado-Filho OV, Borba JB, Maraschin T, Souza LM, Henriques JA, Moreira $\mathrm{JC}$, et al. Effects of chronic exposure to $950 \mathrm{MHz}$ ultra-high-frequency electromagnetic radiation on reactive oxygen species metabolism in the right and left cerebral cortex of young rats of different ages. Int I Radiat Biol. 2015;91(11):891-7.

258. Huss A, Egger M, Hug K, Huwiler-Müntener K, Röösli M. Source of funding and results of studies of health effects of mobile phone use: Systematic review of experimental studies. Environ Health Persp. 2007;115(1):1-4.

Ready to submit your research? Choose BMC and benefit from:

- fast, convenient online submission

- thorough peer review by experienced researchers in your field

- rapid publication on acceptance

- support for research data, including large and complex data types

- gold Open Access which fosters wider collaboration and increased citations

- maximum visibility for your research: over $100 \mathrm{M}$ website views per year

At $\mathrm{BMC}$, research is always in progress.

Learn more biomedcentral.com/submissions 